\title{
Guidance values for microcystins in water and cyanobacterial supplement products (blue-green algal supplements): a reasonable or misguided approach?
}

\author{
Daniel Dietrich, Stefan Hoeger* \\ University of Konstanz, Environmental Toxicology, Germany
}

\begin{abstract}
This article reviews current scientific knowledge on the toxicity and carcinogenicity of microcystins and compares this to the guidance values proposed for microcystins in water by the World Health Organization, and for blue-green algal food supplements by the Oregon State Department of Health. The basis of the risk assessment underlying these guidance values is viewed as being critical due to overt deficiencies in the data used for its generation: (i) use of one microcystin congener only (microcystin-LR), while the other presently known nearly 80 congeners are largely disregarded, (ii) new knowledge regarding potential neuro and renal toxicity of microcystins in humans and (iii) the inadequacies of assessing realistic microcystin exposures in humans and especially in children via blue-green algal food supplements. In reiterating the state-of-the-art toxicology database on microcystins and in the light of new data on the high degree of toxin contamination of algal food supplements, this review clearly demonstrates the need for improved kinetic data of microcystins in humans and for discussion concerning uncertainty factors, which may result in a lowering of the present guidance values and an increased routine control of water bodies and food supplements for toxin contamination. Similar to the approach taken previously by authorities for dioxin or PCB risk assessment, the use of a toxin equivalent approach to the risk assessment of microcystins is proposed.
\end{abstract}

Keywords: Microcystin; Risk assessment; Cyanotoxins

\section{Introduction}

Cyanobacteria are responsible for oxygenic life on earth through their photosynthetic activity and have had more than 3.5 billion years to develop the production of a broad variety of molecules. Peptides such as anabaenopeptins, aeruginosins, microcystins (MCs), nodularins, microginins or microviridins and alkaloids such as anatoxin-a, saxitoxins and cylindrospermopsins do not appear to be necessary for primary metabolism. Although some hypotheses exist (Kaebernick and Neilan, 2001), the physiological function(s) of these molecules either within or outside of the cell

* Corresponding author. University of Konstanz, Environmental Toxicology, Jacob-Burckhardtstr. 25, 78457 Konstanz, Germany. Fax: +497531883170.

E-mail address: stefan.hoeger@uni-konstanz.de (S. Hoeger). is presently unknown. Hundreds of molecules from these families have been structurally identified and many more new compounds will probably be discovered within the next years. Dozens of cyanobacterial species and families produce these secondary metabolites and in principle, every surface water can act as a habitat for cyanobacteria. Furthermore, cyanobacteria occur even in very arid climates (Hitzfeld et al., 2000a; Wynn-Williams, 2000). Parameters such as climate, trophic status and the morphology of the water body determine the composition of the cyanobacterial community. Although there are well-known advantages of these organisms as nitrogen fixers, as succession pioneers, as a first link in the food chain or as potential sources for pharmaceutically relevant compounds (Mundt et al., 2001), cyanobacteria as toxin producers can also have grave disadvantages for humans and their environment, be these through direct or indirect exposure. 
The scope of this review focuses on the possible direct and indirect risks of MCs for human health, while disregarding the additional potential risk presented by other cyanobacterial toxins potentially simultaneously present, which may act synergistically (Fitzgeorge et al., 1994). Prerequisite for any human health risk assessment of chemicals, whether these be of natural or anthropogenic origin (IPCS, 1995), are not only the chemical/biochemical characteristics, kinetics and dynamics (toxicity/carcinogenicity) of the compound(s) in question, but also an understanding of the main routes and possibilities for human contact with the chemical compound(s), in this case MCs. The following paragraphs present merely a brief and condensed overview of the current knowledge on MCs and thus, the reader is referred to the original publications for more detailed information.

\section{Microcystins: chemical and biochemical characteristics}

MCs, cyclic peptides with a molecular weight between 900 and 1100 Daltons, are the most common of the cyanobacterial toxins found in water, as well as being those most often responsible for poisoning animals and humans who come into contact with toxic blooms. Because of their chemical structure, MCs are extremely stable in water and can tolerate radical changes in water chemistry, including $\mathrm{pH}$ (Harada and Tsuji, 1998; Harada et al., 1996). Structurally, $\mathrm{MCs}$ are monocyclic heptapeptides, containing two variable L-amino acids and two novel D-amino acids: $N$-methyldehydroalanine (Mdha), which hydrolyses to methylamine, and a unique non-polar-linked amino acid 3-amino-9methoxy-2,6,8-trimethyl-10-phenyldeca-4,6-dienoic acid, also known as Adda. One of the key components for biological activity appears to be linked with the Adda side chain, as cleavage of the Adda side chain from the cyclic peptide seems to render MCs inactive with regard to protein phosphatase inhibition (Harada et al., 1990a, 1990b). However, the Adda side chain alone has been shown not to inhibit the catalytic subunit of proteinphosphatase 1 even at the extremely high concentration of $10 \mu \mathrm{M}$ and not to be toxic to mice at i.p. doses of up to $10 \mathrm{mg} / \mathrm{kg}$ bw (Harada et al., 2004). MCs are named according to their variable L-amino acid: for example, MC-LR contains leucine and arginine (Carmichael et al., 1988). To date, nearly 80 different congeners have been identified (Sivonen and Jones, 1999).

\section{Microcystins: toxicity and carcinogenicity}

Acute toxicity

MCs have been shown to be acutely toxic to animals and humans (Annadotter et al., 2001; Azevedo et al., 2002; Beasley et al., 1989a; Duy et al., 2000; Hooser et al., 1989; Mez et al., 1997; Pouria et al., 1998; WHO, 1998;
Yoshida et al., 1997) with $\mathrm{LD}_{50} \mathrm{~s}$ of the individual $\mathrm{MC}$ congeners ranging between 50 (MC-LR) and 600 (MC$\mathrm{RR}) \mu \mathrm{g} / \mathrm{kg}$ bw following i.p. injection in mice (Sivonen and Jones, 1999). The primary mechanism of toxicity is probably the inhibition of protein phosphatases 1 and $2 \mathrm{a}$ followed by loss of cytoskeletal integrity and subsequent cytolysis or apoptosis, primarily of hepatocytes but also of glomeruli and renal proximal tubule cells (Eriksson et al., 1990b, 1992; Fischer and Dietrich, 2000a; Fischer et al., 2000b; Hooser et al., 1989; MacKintosh et al., 1990; Wickstrom et al., 1995). The oral $\mathrm{LD}_{50}$ in mice $(5000 \mu \mathrm{g} /$ $\mathrm{kg}$ bw) appears to be approximately a factor 100 lower than the i.p. $\mathrm{LD}_{50}$, while the oral $\mathrm{LD}_{50}$ in rats was reported as $>5000 \mu \mathrm{g} / \mathrm{kg}$ bw, suggesting an even greater difference between p.o. and i.p. application in this species (Fawell et al., 1994, 1999). In addition, Miura et al. (1991) reported a 25-h i.p. $\mathrm{LD}_{50}$ of $122 \mu \mathrm{g}$ MC-LR/kg bw in fed versus an i.p. $\mathrm{LD}_{50}$ of $72 \mu \mathrm{g}$ MC-LR/kg bw in fasted rats. Taken together, the data of Fawell et al. $(1994,1999)$ and Miura et al. (1991) clearly point to the potential weaknesses of such investigations for use in human risk assessment, especially as the oral bioavailability and thus toxicity of MCs appears largely dependent on whether the animals were fasted or not. Indeed, the OECD $401 \mathrm{LD}_{50}$ protocol requires fasting of animals $24 \mathrm{~h}$ prior to oral dosing, with food ad libitum for up to 14 days post-dosing (observation period). If gastrointestinal as well as hepatic uptake of compounds, for example, MCs, is rate-limited via a carrier mediated uptake process (Eriksson et al., 1990a; Fischer and Dietrich, 2000b; Hermansky et al., 1990, 1991; Hooser et al., 1991; Kuiper-Goodman et al., 1994; Kullak-Ublick et al., 1996; Meriluoto et al., 1990; Runnegar et al., 1991, 1995), the $24 \mathrm{~h}$ pre-dosing fasting period may not suffice to provide for a high bioavailability of the compound as the rodents will immediately resume consuming food during the observation period. Furthermore, the question arises whether the rodent food composition is comparable to the food composition generally applicable for humans, that is, whether the bioavailability of MCs is similar in rodent and in human food. In view of this uncertainty and based on the fact that acute intoxication situations in humans are less likely to occur in conjunction with food mixtures (except perhaps blue green algal supplements: (BGAS)), but more likely to occur in conjunction with contaminated water (Annadotter et al., 2001; Hitzfeld et al., 2000a,b; Kuiper-Goodman et al., 1999), thus similar to a "fasted" situation in the rodent, the rodent i.p. $\mathrm{LD}_{50}$ values appear more representative for calculations of an acute intoxication risk in humans than the corresponding p.o. $\mathrm{LD}_{50}$ values.

\section{Subchronic and chronic toxicity}

In studies conducted at the Water Research Center (WRc) in the United Kingdom, MC-LR was also administered orally by gavage to groups of 15 male and 15 
female mice at $0,40,200$ or $1000 \mu \mathrm{g} / \mathrm{kg}$ bw per day for 13 weeks (Fawell et al., 1994, 1999). The no-observed-effect level (NOEL) for liver toxicity was $40 \mu \mathrm{g} / \mathrm{kg}$ bw per day. At the next highest dose level, slight liver pathology was noted in one male and two female mice. At the highest dose level, all mice showed liver changes, which included chronic inflammation, degeneration of hepatocytes and hemosiderin deposits. In addition to the findings of Fawell, Schaeffer et al. (1999), in an effort to prove the lack of health risks stemming from Upper Lake Klamath Aphanizomenon flos-aquae (AFA) bloom material, re-evaluated the following study: young adult mice were treated with AFA bloom material, which corresponded to doses of up to $333 \mu \mathrm{g}$ MC-LR $/ \mathrm{kg}$ bw day, in the rodent feed for up to 43 days. The authors stated that no pathological changes or alterations in blood enzyme levels were observed, thus suggesting a daily intake of $333 \mu \mathrm{g} \mathrm{MC}-\mathrm{LR} / \mathrm{kg}$ bw day to have no effect at all in mice. In a similar study, mice were treated with microcystins containing bloom extract in drinking water for up to 52 weeks (Falconer et al., 1988). The treatment with a high concentration of extract in the drinking water resulted in increased mortality, liver enzyme levels, liver damage and possibly increased renal pathology. No neoplastic nodules were observed in the liver, although a slightly higher number of tumours (carcinomas of the lung and abdomen) were noted in the high-dose group animals when compared to the control. Unfortunately, the toxin concentration was never determined properly, thus a direct comparison with the studies of Fawell or Schaeffer is not possible. In general, it appears that gastrointestinal uptake of MCs in mice is very slow and limited; an observation also supported by the organ distribution studies of Nishiwaki et al. (1994) and
Robinson et al. (1989), where the comparison between i.p and p.o. applications resulted in factor 80 lower amount of radio-labeled dihydro-MC-LR in the liver following p.o. application and comparable time frame of observation postapplication (Table 1).

In a follow-up study with pigs (Falconer et al., 1994) using Microcystis aeruginosa bloom material, animals were exposed to MCs (approximately 7 different congeners including MC-YR but excluding MC-LR and MC-RR) at 1312, 796, 280 and $0 \mu \mathrm{g}$ MC-LR equiv. per $\mathrm{kg}$ bw and day for 44 days in drinking water. All pigs presented with histopathological alterations of the liver even at the lowest dose applied (one animal of five). Consequently, the dose level of $280 \mu \mathrm{g}$ MC-LR equiv./kg bw day should be considered as a lowest-observed-adverse-effect level (LOAEL), when using the toxin concentration estimated from the i.p. equivalent of $100 \mu \mathrm{g}$ MC-LR. If however, the HPLC and the protein phosphatase inhibition test derived $\mathrm{MC}$ equivalent concentrations (summation of visible $\mathrm{MC}$ peaks) are employed, the LOAELs are 184 and $88 \mu \mathrm{g}$ MCLR equiv. $/ \mathrm{kg}$ bw, respectively.

Although the above studies appear to provide conflicting results mainly caused by the different experimental setups, prudence would dictate that the NOEL of $40 \mu \mathrm{g} / \mathrm{kg}$ bw per day, derived from the Fawell study with mice, be used for human health risk assessment purposes. Despite this, the main issue seems, as already noted for the acute toxicity situation, to lie with the bioavailability of MCs. Indeed, MC application within the food appears to provide for the least, within drinking water commensurate with food ad libitum a moderate, and oral gavage of $\mathrm{MC}$, commensurate with water and food ad libitum the highest bioavailability of MCs and consequently liver and possibly

Table 1

Organ distribution of radiolabeled microcystin (MC) congeners, in various species, application routes and time-points post-application

\begin{tabular}{|c|c|c|c|c|c|c|c|c|c|c|c|c|c|c|}
\hline Species & MC-form & $\begin{array}{l}\text { Application } \\
\text { form }\end{array}$ & $\begin{array}{l}\text { Time }{ }^{a} \\
\text { (h) }\end{array}$ & $\begin{array}{l}\text { Liver } \\
(\%)^{\mathrm{b}}\end{array}$ & $\begin{array}{l}\text { Kidney } \\
(\%)^{\mathrm{b}}\end{array}$ & $\begin{array}{l}\text { Brain } \\
(\%)^{\mathrm{b}}\end{array}$ & $\begin{array}{l}\text { Lung } \\
(\%)^{\mathrm{b}}\end{array}$ & $\begin{array}{l}\text { Spleen } \\
(\%)^{b}\end{array}$ & $\begin{array}{l}\text { Heart } \\
(\%)^{b}\end{array}$ & $\begin{array}{l}\text { Gall Bladder } \\
(\%)^{\mathrm{b}}\end{array}$ & $\begin{array}{l}\text { GI-Tract } \\
(\%)^{b}\end{array}$ & $\begin{array}{l}\text { Muscle } \\
(\%)^{b}\end{array}$ & $\begin{array}{l}\text { Carcass }^{\mathrm{c}} \\
(\%)^{\mathrm{b}}\end{array}$ & Ref. \\
\hline \multirow[t]{6}{*}{ Mouse } & ${ }^{3} \mathrm{H}-\mathrm{dhMC}-\mathrm{LR}$ & i.p. & 1.0 & 71.5 & 0.5 & - & 0.4 & - & - & 0.5 & $2.2^{\mathrm{d}}$ & - & - & 1 \\
\hline & ${ }^{3} \mathrm{H}$-dhMC-LR & p.o. & 6.0 & 0.65 & 0.05 & 0.02 & n.d. & n.d. & n.d. & n.d. & 0.69 & n.d. & n.d. & 1 \\
\hline & ${ }^{3} \mathrm{H}$-dhMC-LR & p.o. & 144.0 & 0.4 & 0.01 & - & n.d. & n.d. & n.d. & n.d. & - & n.d. & n.d. & 1 \\
\hline & ${ }^{3} \mathrm{H}-\mathrm{MC}-\mathrm{LR}$ & i.v. & 1.0 & 67.0 & 0.8 & n.d. & $<0.1$ & $<0.1$ & $<0.1$ & n.d. & 8.6 & n.d. & 6.0 & 2 \\
\hline & ${ }^{3} \mathrm{H}-\mathrm{MC}-\mathrm{LR}$ & i.p. & 6.0 & 56.0 & 0.9 & n.d. & $<1.0$ & $<1.0$ & $<1.0$ & n.d. & 7.0 & $<1.0$ & 10.0 & 3 \\
\hline & ${ }^{3} \mathrm{H}-\mathrm{dhMC}-\mathrm{LR}$ & i.v. & 0.45 & 70.0 & 6.0 & 2.0 & n.d. & 2.0 & n.d. & n.d. & 10 & 2.0 & 4.0 & 4 \\
\hline \multirow[t]{2}{*}{ Rat } & ${ }^{125} \mathrm{I}-\mathrm{MC}-\mathrm{YM}$ & i.v. & 2.0 & 19.2 & 5.3 & n.d. & n.d. & n.d. & n.d. & n.d. & 9.4 & n.d. & n.d. & 5 \\
\hline & ${ }^{3} \mathrm{H}-\mathrm{MC}-\mathrm{LR}$ & i.v. & 6.0 & 78.0 & 2.5 & n.d. & n.d. & n.d. & n.d. & n.d. & 3.5 & n.d. & 6.5 & 6 \\
\hline \multirow[t]{3}{*}{ Swine } & ${ }^{3} \mathrm{H}-\mathrm{dhMC}-\mathrm{LR}$ & i.v. & 5.0 & 64.60 & 1.20 & n.d. & 1.75 & 0.04 & 0.22 & n.d. & $0.13^{\mathrm{e}}$ & n.d. & n.d. & $7^{\mathrm{f}}$ \\
\hline & ${ }^{3} \mathrm{H}-\mathrm{dhMC}-\mathrm{LR}$ & i.v. & 5.0 & 46.99 & 2.19 & n.d. & 0.55 & 0.07 & 0.23 & n.d. & $0.20^{\mathrm{e}}$ & n.d. & n.d. & $7^{g}$ \\
\hline & ${ }^{3} \mathrm{H}$-dhMC-LR & i.i.l. & 5.0 & 49.50 & 1.04 & n.d. & 0.65 & 0.16 & 0.81 & n.d. & $33.94^{\mathrm{e}}$ & n.d. & n.d. & $7^{g}$ \\
\hline
\end{tabular}

n.d., not determined; - not detectable; i.p., intraperitoneally; p.o., perorally; i.v., intravenously; i.i.l., intra-isolated ileal loop; bw, body weight. (1) Nishiwaki et al., 1994; (2) Robinson et al., 1991; (3) Robinson et al., 1989; (4) Meriluoto et al., 1990; (5) Falconer et al., 1986; (6) Pace et al., 1990 ; (7) Stotts et al., 1997.

a Time post initial application.

b $[\%]$ denotes $\%$ of dose administered.

c Carcass denotes the sum of all organs if not all organs were individually analysed.

d Small intestine, large intestine and stomach were summed.

e only ileum.

f $25 \mu \mathrm{g} / \mathrm{kg}$ bw.

g $75 \mu \mathrm{g} / \mathrm{kg}$ bw. 
other organ pathologies in rodents and pigs. Thus, for human risk assessment purposes, a detailed understanding of the actual MC exposure scenario becomes crucial for allowing any kind of extrapolation from the animal data presently available.

\section{Tumour promotion}

There has been some evidence of tumour promotion in animal studies, mostly presented in the reviews by Duy et al. (2000) and Kuiper-Goodman et al. (1999). Briefly, when MC-LR was applied to mice i.p. 100 times over 28 weeks, a dose as low as $20 \mu \mathrm{g} / \mathrm{kg}$ bw produced neoplastic liver nodules. These neoplastic lesions appeared to persist 2 months after cessation of exposure (Ito et al., 1997). Conversely, when given 100 times p.o. at a dose of 80 $\mu \mathrm{g} / \mathrm{kg}$ bw over a period of 28 days, the mice presented with neither liver damage nor neoplastic nodules. Furthermore, Sano et al. (2004) treated mice for 14 months with i.p. injections of MC-LR and Dhb-MC-LR $(0,12.5$ and $25 \mu \mathrm{g} / \mathrm{kg} \mathrm{bw}$, once a week), without previous initiation with a DNA damaging compound. While a dose-related increase in hepatic adenomas and adenocarcinomas was observed with MC-LR, no such increase was observed with the Dhb-MC-LR. It is interesting to note in this context that Dhb-MC-RR was demonstrated to inhibit protein phosphatase $2 \mathrm{a}$ less effectively than MC-LR, MCRR and D-Asp-MC-RR (Schmid et al., 2004). Sano et al. (2004) also determined the generation of 8 -OHdG in the liver of mice and observed similar if not higher amounts of 8-OHdG levels in mice treated with Dhb-MC-LR than in mice treated with MC-LR. These findings suggest that the generation of reactive oxygen species and the resulting oxidative DNA damage and transient DNA strand breaks may not be as important in the generation of liver tumours as proposed (Bouaicha and Maatouk, 2004a, 2004b; Zegura et al., 2003) but rather that the inhibition of protein phosphatases plays the central role in MC liver tumourigenesis.

From a risk assessment stand-point, it is important to understand whether MC-LR is biologically available or not, especially when given as a part of the daily food ration. Indeed, in a modified two-stage carcinogenesis mouse skin bioassay, Microcystis extract consumed in drinking water appeared to act as a skin tumour promoter and to induce pronounced liver damage (Falconer, 1991). This highlights the importance of MC bioavailability for the induction of chronic toxicity and tumour promotion. In another twostage carcinogenicity bioassay, groups of 9-15 seven-weekold male Fischer 344 rats were initiated by i.p. injection with diethylnitrosamine (DEN) $(200 \mathrm{mg} / \mathrm{kg} \mathrm{bw})$, followed by partial hepatectomy at the end of the third week. Tumour promotion was assessed by intraperitoneal injection of MCLR at 1 or $10 \mu \mathrm{g} / \mathrm{kg}$ bw twice per week from the third week of the experiment. Tumour promotion, as indicated by an increase in glutathione S-transferase placental form (GST-
P)-positive liver foci, was seen after 8 weeks in animals dosed with MC-LR at $10 \mu \mathrm{g} / \mathrm{kg}$ bw (Nishiwaki-Matsushima et al., 1992). MC-LR had no effect when given to noninitiated rats. Furthermore, treatment of initiated rats with 1 $\mu \mathrm{g} / \mathrm{kg}$ bw did not provide for any significant increase of (GST-P) positive liver foci. To confirm the tumourpromoting activity of MC-LR, the same authors administered MC-LR at a dose of $10 \mu \mathrm{g} / \mathrm{kg}$ bw before partial hepatectomy and 10, 25 or $50 \mu \mathrm{g} / \mathrm{kg}$ bw twice a week after partial hepatectomy to groups of 14-19 male rats. It was found that the increase in GST-P-positive foci following repeated i.p. injections of MC-LR was dose-related. According to the authors, the results suggested MC to be a strong liver tumour promoter. The latter findings were corroborated by Charbonneau et al. (2004), who used aged rats in a similar exposure protocol: a single i.p injection of $200 \mathrm{mg} \mathrm{DEN} / \mathrm{kg}$ bw 2 weeks prior to MC treatment for an additional 7 weeks with a partial hepatectomy at week 3 . As only difference in the Charbonneau study, MC-LR was applied via oral gavage for 7 weeks at doses of 10, 40 and $80 \mu \mathrm{g} / \mathrm{kg}$ bw, or 3 times per week with $10 \mu \mathrm{g} / \mathrm{kg}$ bw via i.p. injection. Increased GST-P-positive foci were observed at the end of the study (67 days) at a dose of $80 \mu \mathrm{g} / \mathrm{kg}$ bw by gavage and $10 \mu \mathrm{g} / \mathrm{kg}$ bw via i.p. injection, demonstrating that chronic oral application of MC-LR can promote preneoplastic lesions in the liver of aged Sprague-Dawley rats. Furthermore, the comparison between the rat and the mouse studies (Charbonneau et al., 2004; Ito et al., 1997; Nishiwaki-Matsushima et al., 1992) strongly suggest that mice may either be generally much less susceptible to oral uptake of MC-LR and thus, to chronic liver damage and tumour promotion than rats or that bioavailability as well as the distribution and elimination pathways and kinetics of the toxin play a much greater role than previously suspected.

\section{Genotoxicity}

MCs, primarily MC-LR, have been tested in the routine type of genotoxicity assays. The results of these assays strongly suggest that moderate to high concentrations of MC-LR are not directly genotoxic (Bouaicha and Maatouk, 2004a; Fessard et al., 2004; Zegura et al., 2003), however, do promote the generation of reactive oxygen species and subsequently lead to oxidative DNA damage and transient DNA strand breaks (Zegura et al., 2003; Bouaicha and Maatouk, 2004a, 2004b). Consequently a tumour initiating capacity of MC-LR has been suggested. This view was corroborated by the findings of Sano et al. (2004), who expressed the opinion that MC-LR induces lipid peroxidative reactions and thus, oxidative DNA damage (mainly 8-OH-dG) but not DNA adducts. A study by Lankoff et al. (2004) suggested that MC-LR-induced DNA damage may be related to the early stages of apoptosis due to cytotoxicity but not genotoxicity and that MC-LR reduces the capability of DNA repair in human peripheral 
lymphocytes following UV damage. However, due to the use of relatively high doses of MC-LR, the relevance of these results is somewhat questionable.

\section{Microcystins: organ specificity/distribution and elimination}

The fact that MCs are termed "hepatotoxins" by many researchers in the field has biased the understanding of organ distribution toward the notion that primarily, if not exclusively, toxicity would and could only occur in the liver. Most acute intoxications, whether in animals or humans, do indeed present with liver pathology (Azevedo et al., 2002; Beasley et al., 2000; Falconer et al., 1981; Fawell et al., 1999; Fischer and Dietrich, 2000a; Fischer et al., 2000b; Harding et al., 1995; Hooser, 2000; Hooser et al., 1991; Mez et al., 1997; Pouria et al., 1998; Puschner et al., 1998). However, despite that the organ distribution studies reported to date are somewhat controversial, due to the variant application modes and the use of different MC congeners (Table 1), most studies have clearly demonstrated that, for example, MC-LR can be also found in the kidneys and the brain. This is not only corroborated by the fact that MC protein adducts can be found in several organs, for example, kidneys, brain, muscle (Fischer et al., 2000a), but also by the pathological and symptological evidence for renal and/or neurological damage in animals and humans (Azevedo et al., 2002; Beasley et al., 2000; Fischer and Dietrich, 2000a; Krienitz et al., 2003; Milutinovic et al., 2002; Nobre et al., 1999, 2001; Pennycott et al., 2004). A most likely explanation for the assumption that primarily hepatotoxicity would occur is the fact that it was realised very early on that MCs cannot permeate across cell membranes but are transported actively into hepatocytes via organic anion transporters (Runnegar et al., 1991), for which bile acid salts (cholate and taurocholate) amongst others, are the "natural" substrates (Frimmer and Ziegler, 1988; Meier, 1996; Meier and Stieger, 2002; Meier et al., 1997; Takikawa, 2002). However, these organic anion transporters are not only expressed in the liver but also in the gastrointestinal tract, the kidney and the brain (blood-brain barrier) (Craddock et al., 1998; Hagenbuch and Meier, 2003; Kullak-Ublick et al., 1998; Kusuhara et al., 1999; Nobre et al., 1999). Indeed, the most recent evidence strongly suggests that MC-LR can be transported across the human blood-brain barrier (Fischer et al., 2004), thus potentially explaining some of the observed neurological symptoms observed in the fatal incident at the renal dialysis station in Cuaruaru, Brazil (Azevedo et al., 2002; Pouria et al., 1998). It may be assumed at present that the organ distribution of MCs is governed by the presence/absence, type and expression level (number of functional transporters per cell) of organic anion transporters. As saturation kinetics have only been carried out with ${ }^{3} \mathrm{H}$-dihydro-MC-LR, this implies that similar experiments should be carried out with a representative subset of the nearly 80 different MC congeners known to date in order to gain a better understanding of the distribution and elimination kinetics of these toxins. Indeed, when using different epimers of ${ }^{3} \mathrm{H}$-dihydro-MCLR, Meriluoto et al. (1990) found one of the epimers to be taken up and distributed across the different organs three to four times faster than the other epimer. This strongly suggests that minimal structural changes in the MC molecule can have major implications for the uptake, organ distribution and excretion kinetics, which are most likely governed by the affinity of the respective $\mathrm{MC}$ for the organic anion transport proteins. Furthermore, the analysis of $\mathrm{MC}$ metabolism has demonstrated that MCs are primarily conjugated and then excreted either as parent compound or conjugate via the bile or the urine (Dahlem et al., 1989; Falconer et al., 1986; Hermansky et al., 1991; Kondo et al., 1992; Milutinovic et al., 2002; Nishiwaki et al., 1994; Robinson et al., 1989, 1991; Takenaka, 2001), probably involving the same organic anion transport proteins. Of importance is also that after moderate liver damage, for example, in MC-LR-dosed pigs, a reduced MC-LR clearance can be observed in the blood, resulting in an extended availability of MC-LR for uptake into other organs such as the kidneys (Stotts et al., 1997). Consequently, pathological changes are observed in those organs. This may be of importance especially in the chronic exposure scenario, where humans with impaired liver function or lowered expression of organic anion transporters in the liver could display a longer blood halflife of MCs and could thus be prone to a higher risk for kidney or brain pathology.

When comparing the blood half-lives of $\mathrm{MC}$ in different species, quite clearly a congener-dependent effect is evident. Indeed, while a plasma half-life of ${ }^{125} \mathrm{I}-\mathrm{MC}-\mathrm{YM}$ of $42 \mathrm{~min}$ (i.v. application) was reported for adult female rats (Falconer et al., 1986), an application of ${ }^{3} \mathrm{H}-\mathrm{MC}-\mathrm{LR}$ (i.v. in rats) resulted in a half-life of $70 \mathrm{~min}$ (Pace et al., 1990). In contrast, an i.v. application of ${ }^{3} \mathrm{H}-\mathrm{MC}-\mathrm{LR}$ in mice resulted in a plasma half-life of 6.9 min (Robinson et al., 1991), thus strongly suggesting that for MC plasma half-life species-specific effects may be as important as the $\mathrm{MC}$-structure. In view of these species and congener specificities, a better understanding of congener-specific MC kinetics in general, and especially in humans, appears crucial for an improved assessment of risk in a chronic exposure setting.

\section{The principles of assessing human health risks applied to microcystins}

In order to highlight the possible problems in the risk assessment of MCs, the current knowledge on MCs is put into context with the principles and type of information employed for assessing human health risk of chemicals 
(IPCS, 1995), by first describing the techniques underlying the risk assessment process followed by a discussion of possible weaknesses in the MC data set.

The aim of the IPCS risk assessment process is to derive a tolerable daily intake (TDI) of a compound for various routes of exposure for effects considered to have a threshold. "The TDI is defined as an estimate of the intake of a substance over a lifetime that is considered without appreciable health risk. Its units depend on the route of administration (e.g., $\mathrm{mg} / \mathrm{l}$ water; $\mathrm{mg} / \mathrm{kg}$ food, etc.)". Within this context, estimation of the TDI involves the application of uncertainty factors, generally to the no-observed-adverseeffect-level (NOAEL), for critical effects in the most relevant study or studies (Fig. 1). Of essence with regard to MCs is the fact that the IPCS document emphasises that a TDI can only be developed on the basis of a NOAEL "for substances where the critical effect is considered to have a threshold (including non-genotoxic carcinogenesis for which there is adequate mechanistic data)" (IPCS, 1995). Although MC-LR was shown not to have genotoxic

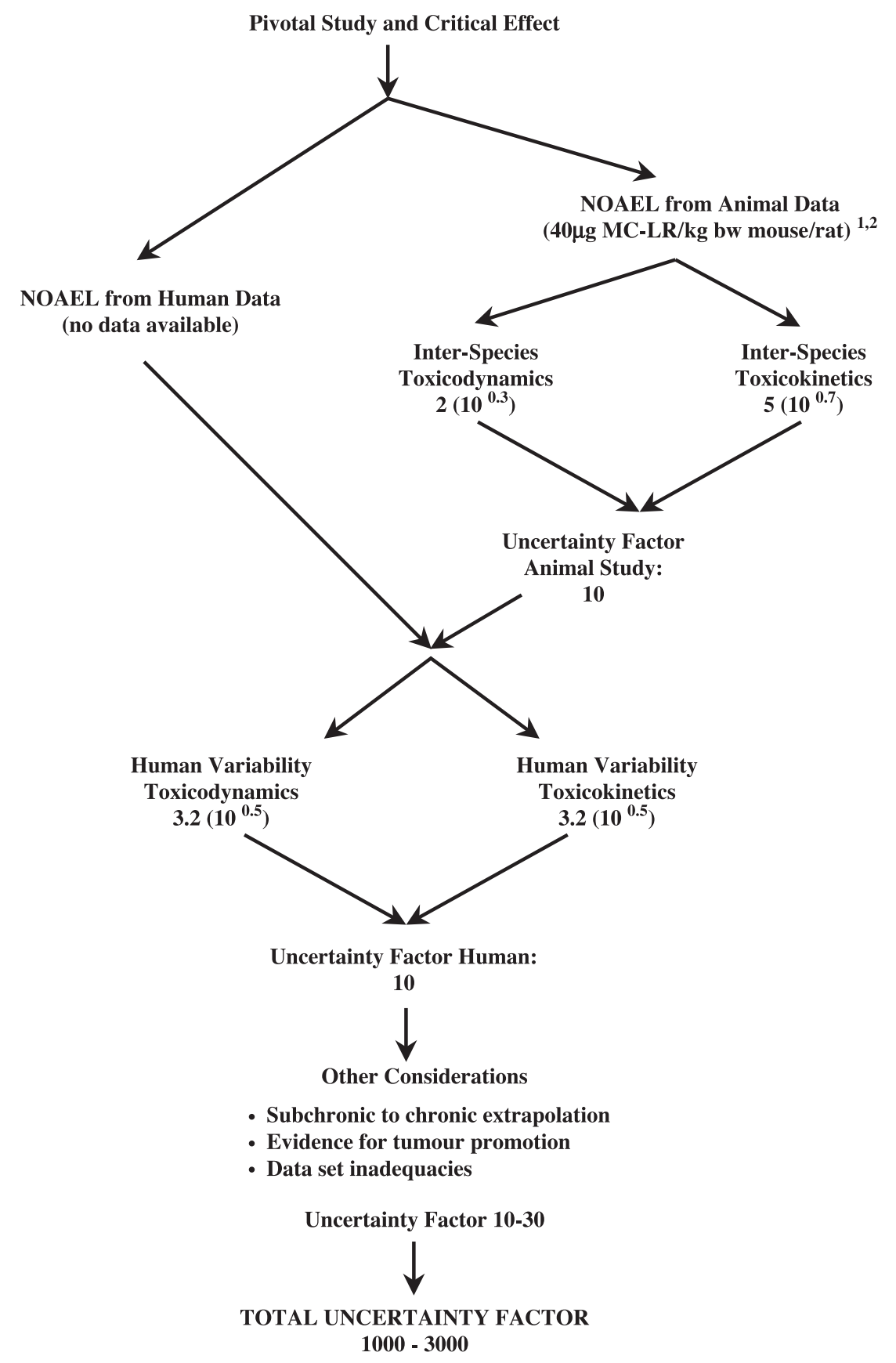

Fig. 1. Procedures for the derivation of uncertainty factors for the development of a tolerable daily intake (TDI) of microcystin-LR (adapted from IPCS, 1995. 1: Fawell et al., 1994, 1999; 2: Charbonneau et al., 2004). 
activities and a threshold (NOAEL) of $40 \mu \mathrm{g}$ MC-LR/kg bw for the generation of liver preneoplastic lesions was observed in mice and rats (Fawell et al., 1999; Charbonneau et al., 2004), the mechanistic understanding of MC-LRinduced liver tumours and the associated data appears at present far from adequate. Despite this and in view of the fact that both the mouse and rat data for MC-LR demonstrated a NOAEL of $40 \mu \mathrm{g}$ MC-LR/kg bw for chronic liver toxicity and preneoplastic lesions in the liver, it appears reasonable to use this data to derive a TDI for MC-LR (Fig. 1). Although the mouse to rat NOAEL and acute toxicity comparison a priori would not indicate large species differences in toxicodynamics (uncertainty factor 2), differences in the kinetics due to variant expression of organic anion transporters (uncertainty factor 5) suggest that a total uncertainty factor of 10 is advisable. In case of human (intra-species) variability, equal uncertainty (total uncertainty of 10) was attributed to dynamics and kinetics, especially as in vitro assays with primary hepatocytes indicated similar if not higher susceptibility of human hepatocytes to MC-LR than rat primary hepatocytes (Batista et al., 2003) and human organic anion transporter analysis has suggested a higher transport in human than in rat liver (Fischer et al., 2004). These uncertainty factors should also account for potential enzyme polymorphisms (e.g., glutathione transferase isoenzymes (Landi, 2000; Habdous et al., 2004)) that could substantially alter the metabolism and excretion of MC-LR. Finally, an additional uncertainty factor of 10-13 can be applied for additional issues, for example, inadequacies in the durations of the pivotal studies (subchronic to chronic extrapolation), tumour promotion and lack of appropriate developmental studies. The degrees of uncertainty attributed to these other considerations have been intensively discussed (Table 1) and have led to diverse opinions, some considering an uncertainty factor of 10 (total of 1000) to be sufficient (Falconer et al., 1994; Gilroy et al., 2000), while others support a factor of 10 plus an additional factor 3 (total of 3000) for tumour-promoting activity (Duy et al., 2000). Some agreement is found in the literature suggesting that the total uncertainty factor to be applied to the data set should range between 1000 and 3000, although this difference would amount to a TDI of $0.013-0.04 \mu \mathrm{g}$ MC-LR/kg bw/day (Eq. (1)). The provisional WHO-guideline (WHO, 1998) for drinking water as well as the Oregon Health Division (Gilroy et al., 2000) for BGAS currently use $0.04 \mathrm{MC}-\mathrm{LR} / \mathrm{kg}$ bw/day as the TDI for calculation of guidance values (Table 2).

$$
\begin{aligned}
T D I & =\frac{N O A E L \text { or } L O E L}{U F}=T D I(M C-L R) \\
& =\frac{40 \mu \mathrm{g} / \mathrm{kg} \mathrm{bw}}{1000(3000)}=0.04(0.013) \mu \mathrm{g} / \mathrm{kg} \mathrm{bw}
\end{aligned}
$$

TDI: Tolerable Daily Intake; NOAEL: Nxo Observed Adverse Effect Level; LOEL: Lowest Observed Effect Level; UF: Uncertainty Factors.
In a second step, the proportion of total intake that originates from various sources of exposure (e.g., drinking water, food, etc.) is estimated, based on exposure estimates from a consistent set of assumed volumes of intake and representative concentrations in the general environment, for a given situation. These proportions, often termed "allocation factors", are then multiplied by the body weight of an "international unit adult" (60 or $70 \mathrm{~kg}$ ) and the TDI and divided by the daily intake of the source (water, food, etc.) thus providing a "guidance value" (GV) for the maximal acceptable concentration (MAC) in a given exposure source (Eq. (2)).

$G V(M A C)=\frac{T D I \times b w \times A F}{C}$

GV: guidance value (e.g., $\mu \mathrm{g} \mathrm{MC}-\mathrm{LR} / \mathrm{l}$ water, $\mathrm{kg}$ food or $\mathrm{g}$ BGAS); MAC: maximal acceptable concentration; bw: body weight of an "international unit adult" (60 or $70 \mathrm{~kg})$; AF: allocation factor, or percentage of the total exposure from a given source; $C$ : amount of daily exposure from a given source (e.g., 21 drinking water, $0.1 \mathrm{~kg}$ fish, $2 \mathrm{~g}$ BGAS).

Thus, using the TDIs calculated above and varying bodyweights for adults and children, diverse guidance values (GV) are derived for various sources of exposure, for example, water and food (Table 3 ). The guidance values largely depend on how strongly the individual experts evaluated the degree of uncertainty in the data sets at hand. However, from the presently available data, it can be stated that the toxicity and carcinogenicity data on MC-LR are the best available, while all other data sets have strong confounders (Table 2). Of utmost importance with regard to actual exposure and hence risk determination is the paucity of data with regard to MC congeners other than MCLR. Especially congener-specific uptake and distribution, as discussed above, may strongly govern the subsequent toxicodynamics and perhaps most importantly the development of chronic toxic effects and tumour promotion. In addition, as the current TDI was based on the occurrence of chronic liver toxicity or the presence of preneoplastic lesions in the liver, other apical endpoints, for example, neuropathy or nephropathy may be severely underestimated. Furthermore, it is at present unclear how best to incorporate the simultaneous occurrence of several different $\mathrm{MC}$ congeners into a risk assessment framework. One possibility would be to deal with the MC congener mixtures as was established for dioxins and PCBs in that a toxicity equivalent approach was taken while including kinetic determinants of each congener for the derivation of equivalents. This would however assume additivity of toxicity of the various congeners and demand the establishment of the individual kinetic values for many if not all of the MC congeners. Irrespective of these caveats, the TDIs developed for MC-LR should be employed to derive guidance values for various exposure scenarios and sources. 
Studies on MC toxicity after oral administration with food or drinking water

\begin{tabular}{|c|c|c|c|c|c|c|c|c|c|c|c|c|}
\hline & \multirow{2}{*}{$\begin{array}{l}\text { Test } \\
\text { organism }\end{array}$} & \multirow{2}{*}{$\begin{array}{l}\text { Administration } \\
\text { of }\end{array}$} & \multirow[t]{2}{*}{ Duration } & \multirow[t]{2}{*}{ NOAEL } & \multicolumn{5}{|c|}{ Uncertainty Factors (UF) } & \multirow{2}{*}{$\begin{array}{l}\text { Sum of } \\
\text { UF }\end{array}$} & \multirow{2}{*}{$\begin{array}{l}\text { Calc. } \\
\text { TDI }\end{array}$} & \multirow[t]{2}{*}{ Guideline value } \\
\hline & & & & & $\begin{array}{l}\text { Intraspecies } \\
\text { variability }\end{array}$ & $\begin{array}{l}\text { Interspecies } \\
\text { variability }\end{array}$ & TPC & $\begin{array}{l}\text { Lack of } \\
\text { data on } \\
\text { chronic } \\
\text { toxicity }\end{array}$ & $\begin{array}{l}\text { LOEL to } \\
\text { NOAEL }\end{array}$ & & & \\
\hline $\begin{array}{l}\text { Falconer } \\
\text { et al., } \\
1988, \\
\text { Carmichael } \\
\text { and } \\
\text { Falconer, } \\
1993\end{array}$ & mice & Microcystis sp. & 1 year & 500 & 10,000 & & & & & 10,000 & 0.05 & $1.5 \mu \mathrm{g} / \mathrm{l}^{\mathrm{a}}$ \\
\hline \multirow[t]{2}{*}{$\begin{array}{l}\text { Falconer et al., } \\
\quad 1994\end{array}$} & pigs & $\begin{array}{l}\text { M. aeruginosa } \\
\text { extract }\end{array}$ & 44 days & $\begin{array}{l}280 \\
\text { (LOEL) }\end{array}$ & 10 & 10 & - & - & 10 & 1000 & 0.28 & $8.4 \mu \mathrm{g} / 1^{\mathrm{a}}$ \\
\hline & & & & & & & 10 & & 10 & 10,000 & 0.028 & $0.84 \mu \mathrm{g} / \mathrm{l}^{\mathrm{a}}$ \\
\hline $\begin{array}{l}\text { Fawell et al., } \\
1994,1999\end{array}$ & mice & MC-LR & 13 weeks & 40 & 10 & 10 & 10 & & - & 1000 & 0.04 & $0.96 \mu \mathrm{g} / \mathrm{l}^{\mathrm{b}, \mathrm{c}}$ \\
\hline $\begin{array}{l}\text { Schaeffer et al., } \\
1999\end{array}$ & mice & BGAS & 43 days & 333 & 1000 & & & & & 1000 & 0.333 & $10 \mu \mathrm{g} / \mathrm{g}^{\mathrm{d}}$ \\
\hline \multirow[t]{2}{*}{$\begin{array}{l}\text { Duy et al., } \\
2000\end{array}$} & \multicolumn{2}{|c|}{$\begin{array}{l}\text { Based on } \\
\text { data of } \\
\text { (Fawell et al., } \\
\text { 1999) study }\end{array}$} & & 40 & 10 & 10 & 3 & 10 & - & 3000 & 0.0133 & $\begin{array}{l}0.32 \mu \mathrm{g} / 1^{\mathrm{c}} \\
0.11 \mu \mathrm{g} / \mathrm{l}^{\mathrm{e}} \\
0.07 \mu \mathrm{g} / 1^{\mathrm{f}}\end{array}$ \\
\hline & \multicolumn{2}{|c|}{$\begin{array}{l}\text { Based on } \\
\text { data of } \\
\text { (Falconer et al., } \\
\text { 1994) study }\end{array}$} & & 186 & 10 & 10 & & 10 & 5 & 5000 & 0.0368 & $\begin{array}{l}0.88 \mu \mathrm{g} / 1^{\mathrm{c}} \\
0.29 \mu \mathrm{g} / \mathrm{l}^{\mathrm{e}} \\
0.20 \mu \mathrm{g} / \mathrm{l}^{\mathrm{f}}\end{array}$ \\
\hline $\begin{array}{l}\text { Kuiper- } \\
\text { Goodman } \\
\text { et al., } 1999\end{array}$ & \multicolumn{2}{|c|}{$\begin{array}{l}\text { Based on } \\
\text { data of } \\
\text { (Falconer et al., } \\
\text { 1994) study }\end{array}$} & & 100 & 10 & 3 & & 10 & 5 & 1500 & 0.067 & $1.0 \mu \mathrm{g} / \mathrm{l}^{\mathrm{c}}$ \\
\hline $\begin{array}{l}\text { Gilroy et al., } \\
2000\end{array}$ & \multicolumn{2}{|c|}{$\begin{array}{l}\text { Based on } \\
\text { data of } \\
\text { (Fawell et al., } \\
\text { 1999) study }\end{array}$} & & 40 & 10 & 10 & 10 & & - & 1000 & 0.04 & $1.0 \mu \mathrm{g} / \mathrm{g}^{\mathrm{d}}$ \\
\hline
\end{tabular}

Data from Fawell et al. $(1994,1999)$ together with data from Falconer et al. (1994) form the basis for the WHO provisional guideline for MC-LR in drinking water of $1.0 \mu \mathrm{g} / \mathrm{l}$. Australia, Brazil, Canada, France, the Czech Republic, Poland, Spain and New Zealand assumed this guideline value, partly with slight changes due to different assumptions concerning the average body weight of consumers and the average daily consumption of drinking water.

a $60 \mathrm{~kg} ; 2$ 1/day; allocation factor (AF) 1 (drinking water).

b Calculation by WHO (WHO, 1998).

c $60 \mathrm{~kg}, 2 \mathrm{l} / \mathrm{day}$, AF 0.8 (drinking water).

d $60 \mathrm{~kg} ; 2 \mathrm{~g} / \mathrm{day} ;$ AF 1 (BGAS).

e $10 \mathrm{~kg}, 1$ 1/day, AF 0.8 (drinking water).

\section{Microcystin: risk assessment and guidance values for various exposure scenarios}

\section{Microcystins: main routes of human contact (exposure scenarios)}

In order to evaluate the potential risk associated with $\mathrm{MC}$ exposure in humans, various exposure scenarios need to be distinguished:

I. accumulation of cyanobacterial toxins in the food chain, for example, contaminated food (e.g., lettuce) after irrigation with toxin-rich water, cyanobacterial blooms in rice fields and MCs accumulated in fish, crayfish and shellfish.
II. dermal, nasal or oral (accidental ingestion) contact during recreational use of water.

III. drinking water and intoxication during hemodialysis.

IV. involuntary exposure via contaminated blue-green algal food supplements (BGAS).

The order of importance (exposure) of the individual routes varies between countries and largely depends on factors such as climatic conditions, eating habits of the local population, drinking water source and the drinking water treatment in the individual regions, and last but not least, the economical affluence of the population in question (e.g., North America, Western Europe) that allows spending vast amounts of funds for seemingly healthy and healthpromoting bio-products (Willett et al., 2004), of which 
Table 3

Daily tolerable total microcystin-LR exposure based on two different TDIs, concurrent calculations of guideline values (GV) for food (fish: $0.1 \mathrm{~kg}$ day) and water ( $0.75 \mathrm{l}$ /day for infants, $1.0 \mathrm{l}$ /day for children; $2 \mathrm{l}$ /day for adults)

\begin{tabular}{cllll}
\hline & $\begin{array}{l}\text { TDI } \\
(\mathrm{MC}-\mathrm{LR} / \\
\mathrm{kg} \mathrm{bw} / \\
\text { day })\end{array}$ & $\begin{array}{l}\text { GV MC-LR/d } \\
\text { exposure } \\
(\mu \mathrm{g})\end{array}$ & $\begin{array}{l}\text { GV MC-LR/ } \\
\mathrm{kg} \text { food }(\mu \mathrm{g})\end{array}$ & $\begin{array}{l}\text { GV MC-LR/ } \\
1 \text { drinking } \\
\text { water }(\mu \mathrm{g})\end{array}$ \\
\hline Infants & 0.04 & 0.20 & & \\
$5 \mathrm{~kg}$ & $0.013^{\mathrm{a}}$ & 0.065 & 0.40 & 0.21 \\
Children & 0.04 & 0.80 & 0.13 & 0.07 \\
$20 \mathrm{~kg}$ & $0.013^{\mathrm{a}}$ & 0.26 & 1.60 & 0.64 \\
Adults & 0.04 & 2.40 & 0.52 & 0.21 \\
$60 \mathrm{~kg}$ & $0.013^{\mathrm{a}}$ & 0.78 & 4.80 & 0.96 \\
Adults & 0.04 & 2.80 & 1.56 & 0.31 \\
$70 \mathrm{~kg}$ & $0.013^{\mathrm{a}}$ & 0.91 & 5.60 & 1.12 \\
\hline
\end{tabular}

The allocation factor (AF) for food was estimated as 0.2 in case of primarily fish and shellfish consuming populations in contaminated areas; the allocation factor for drinking water was estimated as 0.8 .

a This TDI includes an additional uncertainty factor of 3 for tumour promoting capacity, i.e. a total uncertainty factor (UF) of 1300).

blue-green algae supplements (BGAS) are an economically important representative. The potential exposure routes are listed here in order of perceived increasing importance, although it must be noted that exposure routes III and IV at present appear to be of equal importance, when considering the risk of acute and chronic exposure to potentially toxic/ carcinogenic concentrations of MCs.

I. MCs are known to be taken up by commercially cultivated plants such as lettuce (Lactuca sativa) (Codd et al., 1999) and the common bean (Phaseolus vulgaris) (Abe et al., 1996), provided that the toxins are present in the irrigation water or the growing media. As some cyanobacteria can fix nitrogen from the atmosphere and hence provide a valuable nitrogen source for the growing rice plants after lysis of the cyanobacterial cells, cyanobacteria are welcome in rice fields (Rahman et al., 1996). However, little is known about the uptake mechanism(s) of MCs into plants and the concentration of toxic cyanobacterial compounds in rice fields. Thus, the level of contribution to the overall exposure of humans to cyanobacterial toxins and hence the risk for human health arising from these sources is presently difficult to estimate. MCs (and other cyanobacterial toxins) can also accumulate in fish, crayfish and shellfish (Ernst et al., 2000, 2001; Kankaanpää et al., 2004; Magalhaes et al., 2001, 2003; Mohamed et al., 2003; Vasconcelos, 1999) with maximum MC-concentrations of $300 \mu \mathrm{g} / \mathrm{kg}$ in the edible parts of fish, $2700 \mu \mathrm{g} /$ $\mathrm{kg}$ in crayfish and $16000 \mu \mathrm{g} \mathrm{MC}-\mathrm{LR} / \mathrm{kg}$ in mussels. At present, little data exist concerning the accumulation of cyanobacterial toxins in livestock (e.g., cattle, swine, sheep). It is known that, for example, in Australia, the USA and alpine regions of Switzerland (Beasley et al., 1983, 1989a, 1989b; Mez et al., 1997) livestock may be frequently exposed to MCs and other cyanobacterial toxins via consumption of water contaminated with cyanobacteria. However, current studies suggest no carry-over of MCs into milk (Orr et al., 2001) or meat (Orr et al., 2003) in cows after oral application of toxic $M$. aeruginosa via drinking water.

II. A number of the toxin producing cyanobacteria demonstrate mass development during late spring, summer and early autumn months, that is, during the time many people use water bodies for recreational purposes. In $2 \%$ of 128 samples from recreation sites near Berlin, Germany, more than $100 \mu \mathrm{g}$ MC-LR equiv./1 water could be detected, $74 \%$ contained $>1.0$ $\mu \mathrm{g}$ MC-LR equiv./l (Fromme et al., 2000). It has generally been found that $50-75 \%$ of bloom isolates are capable of producing toxins, with often more than one toxin (e.g., MCs and anatoxin-a) and several MC congeners being simultaneously produced. Concentrations of more than $24,000 \mu \mathrm{g} \mathrm{MCs} / 1$ have been reported from the shores of the Havel River, Berlin, Germany (Fastner et al., 1999) and Lake Akersvatn, Norway (Berg et al., 1987). Germany could exemplify for the widespread occurrence of toxic cyanobacterial blooms as documented in the literature (Wiedner et al., 2001). In addition, the overall toxicity of a bloom cannot be defined because of variations in toxin concentration temporally and spatially within a water body experiencing the bloom. There may be also large year-to-year fluctuations in the levels of cyanobacteria and their toxins (Hoeger, 2003; Hoeger et al., 2004b; Park et al., 1993) and seasonal variations with regard to the dominant species of toxic cyanobacteria and hence, the toxins present (Henriksen and Moestrup, 1997; Hoeger et al., 2004b; Xu et al., 2000).

III. Of all exposure scenarios, drinking water is, in a worldwide view, the main source for the incorporation of cyanobacterial toxins for humans. The published cases of cyanobacterial toxins in raw water, during drinking water treatment and even in finished water are numerous and problematic worldwide. MCs have been reported in final water in Argentina, Australia, Bangladesh, Canada, Czech Republic, China, Finland, France, Germany, Latvia, Poland, Thailand, Turkey, Spain, Switzerland and USA (Westrick, 2003; Hoeger et al., 2004a, 2004b). Up to 9000 cells $/ \mathrm{ml}$ were detectable even after treatment in Argentina, Australia, Finland, Germany, Israel and Italy. It must be assumed that this is only the tip of the iceberg, especially as water works are not primarily interested in publishing reports regarding toxins or cyanobacterial cells in their raw or final water. In many cases worldwide, the drinking water is simply not screened for cyanotoxins. In addition, more than one billion people have no access to "treated" drinking water, in many cases, 
the drinking water is simply boiled, which does not destroy most of the known cyanobacterial toxins. In fact, most of the people affected by gastroenteritis at Itaparica dam/Brasilia (Teixera et al., 1993) boiled the drinking water before use. It is likely that the boiling actually exacerbated the problem by causing lysis of the cyanobacterial cells resulting in toxin release. In a sugar refinery in Scania, Sweden, the drinking water distribution system was erroneously coupled to untreated river water (Annadotter et al., 2001). Coincidentally, a high density of $P$. agardhii occurred in this river and the water contained approximately $1.0 \mu \mathrm{g}$ MC-LR equiv./1. In the following days, 121 persons, who consumed the contaminated water, developed numerous symptoms including diarrhoea, headache, vomiting, fever and muscular and abdominal pain. Pathogenic bacteria or viruses could be excluded as the cause for the illnesses. As another interesting fact, $100 \%$ of the tea-drinkers of the sugar refinery were sick in the days following the accident, while none of the coffee-drinkers were affected. It is likely that the toxins were released from the cells by boiling the water and, in the case of the coffee-drinkers, filtered out by the use of a coffee filter and the coffee grinds. The tea-drinkers just put the teabag in the boiled water and consumed the whole cocktail of heat-resistant cyanobacterial metabolites. Thus, it can be assumed that cyanotoxins at least participated in the observed symptoms. Other cases of human illnesses are described in the literature, where cyanobacterial toxins are suspected to be at least involved in the intoxication of the affected population (de Olivera Araújo, 1995; Falconer et al., 1983; Yu, 1995; Zilberg, 1966). However, intoxication may not only occur via consumption of drinking water, but also through hemodialysis as was reported from Portugal (Pereira et al., 2000), USA (Hindman et al., 1975) and Brazil (Azevedo et al., 2002; Pouria et al., 1998), where the severe intoxication and death of patients were most likely caused by intravenous exposure to cyanobacterial toxins.

IV. Several regions worldwide such as Mexico, northern Africa and China have a history of the use of bluegreen algae (Spirulina and Nostoc spp.) as a food source (Carmichael et al., 2000; Jensen et al., 2001). Nowadays, blue-green algal supplements (BGAS), mainly products of Aphanizomenon flos-aquae and Spirulina spp., represent an important economic branch (Carmichael et al., 2000), while being sold mainly in the industrialised countries. These supplements are commonly consumed for their putative beneficial health effects, for example, increased alertness, increased energy, "detoxification", elevated mood and weight loss (Jensen et al., 2001). Moreover, some of the products are specifically marketed for use by children as a replacement or alternative for the pharmacological therapy of Attention Deficit Hyperactivity Disorder (ADHD) (Lindermann, 1995). Although the providers of Aphanizomenon flos-aquae based BGAS state that they screen out MC-levels of more than $1.0 \mu \mathrm{g} / \mathrm{g} \mathrm{dw}$ in their products (Carmichael et al., 2000), independent investigations into the MC contamination of BGAS products have demonstrated toxin concentrations of up to $35 \mu \mathrm{g} / \mathrm{g}$ dw (Gilroy et al., 2000; Lawrence et al., 2001). Although samples with toxin contaminations of more than $10 \mu \mathrm{g}$ MC-LR equivalents/g $\mathrm{dw}$ are the exception, 8 of 13 blue-green algae products from the German and Swiss markets tested recently have shown more than $1.0 \mu \mathrm{g}$ MC-LR equiv./g DW in concurrent analyses (Hoeger and Dietrich, 2004) carried out with an Adda-ELISA (Fischer et al., 2001) and cPPA (Heresztyn and Nicholson, 2001). Our own studies (Hoeger and Dietrich, 2004) and the study of Lawrence et al. (2001) have shown differences in detectable toxin amounts when employing ELISA, PPA and LC-MS/MS. These differences appear to stem from the lack of certified standards for 5 to 10 of the $\mathrm{MC}$ congeners commonly detected in BGAS, but may also be due to some differences in the $\mathrm{MC}$ congener cross-reactivity of some of the respective antibodies in the ELISAs employed. Thus, the values obtained can only be taken as an estimation of the MC content in BGAS. Within this context it is also important to understand that not all Aphanizomenon flos-aquae-based BGAS show high levels of MCs (above $1.0 \mu \mathrm{g}$ MC-LR equiv./g dw) and that the levels of MCs in a given brand name can vary extensively from batch to batch (Gilroy et al., 2000; Hoeger and Dietrich, 2004).

Table 4

Daily tolerable total microcystin-LR exposure based on two different TDIs, concurrent calculations of guideline values (GV) for different blue green algal supplements (BGAS) - doses taken per day

\begin{tabular}{cllll}
\hline & $\begin{array}{l}\text { TDI } \\
\text { (MC-LR/ } \\
\text { kg bw/day) }\end{array}$ & $\begin{array}{l}\text { GV MC-LR/d } \\
\text { exposure } \\
(\mu \mathrm{g}), \text { daily } \\
\text { consumption } \\
1 \mathrm{~g}\end{array}$ & $\begin{array}{l}\text { GV MC-LR/g } \\
\text { dw BGAS } \\
(\mu \mathrm{g}), \text { daily } \\
\text { consumption } \\
2 \mathrm{~g}\end{array}$ & $\begin{array}{l}\text { GV MC-LR/g } \\
\text { dw BGAS } \\
(\mu \mathrm{g}), \text { daily } \\
\text { consumption } \\
10 \mathrm{~g}\end{array}$ \\
\hline Infants & 0.04 & 0.20 & 0.10 & 0.02 \\
$5 \mathrm{~kg}$ & $0.013^{\mathrm{a}}$ & 0.065 & 0.03 & 0.0065 \\
Children & 0.04 & 0.80 & 0.40 & 0.08 \\
$20 \mathrm{~kg}$ & $0.013^{\mathrm{a}}$ & 0.26 & 0.13 & 0.026 \\
Adults & 0.04 & 2.4 & 1.20 & 0.24 \\
$60 \mathrm{~kg}$ & $0.013^{\mathrm{a}}$ & 0.78 & 0.39 & 0.078 \\
Adults & 0.04 & 2.8 & 1.40 & 0.28 \\
$70 \mathrm{~kg}$ & $0.013^{\mathrm{a}}$ & 0.91 & 0.46 & 0.091 \\
\hline
\end{tabular}

The allocation factor (AF) for BGAS was estimated as 1 .

a This TDI includes an additional uncertainty factor of 3 for tumour promoting capacity, that is, a total uncertainty factor (UF) of 3000 . 
Table 5

Calculated possible daily ingestion to avoid acute health problems according to the calculations of Fromme et al. (2000)

\begin{tabular}{cllll}
\hline Ingestion route & $\begin{array}{l}\text { MC } \\
\text { concentrations }\end{array}$ & $\begin{array}{l}\text { Infants } \\
5 \mathrm{~kg}= \\
12.5 \mu \mathrm{g}\end{array}$ & $\begin{array}{l}\text { Children } \\
20 \mathrm{~kg}= \\
50 \mu \mathrm{g}\end{array}$ & $\begin{array}{l}\text { Adults } \\
60 \mathrm{~kg}= \\
150 \mu \mathrm{g}\end{array}$ \\
\hline Food (1) & $100 \mu \mathrm{g} / \mathrm{kg}$ & $125 \mathrm{~g}$ & $500 \mathrm{~g}$ & $1500 \mathrm{~g}$ \\
& $10,000 \mu \mathrm{g} / \mathrm{kg}$ & $1.25 \mathrm{~g}$ & $5 \mathrm{~g}$ & $15 \mathrm{~g}$ \\
Cyanobacterial & $100 \mu \mathrm{g} / \mathrm{l}$ & $125 \mathrm{ml}$ & $500 \mathrm{ml}$ & $1500 \mathrm{ml}$ \\
bloom in & $1000 \mu \mathrm{g} / 1$ & $12.5 \mathrm{ml}$ & $50 \mathrm{ml}$ & $150 \mathrm{ml}$ \\
lake/river (2) & & & & \\
Drinking water & $1.0 \mu \mathrm{g} / 1$ & $12,500 \mathrm{ml}$ & $50,000 \mathrm{ml}$ & $150,000 \mathrm{ml}$ \\
$\quad(3)$ & $100 \mu \mathrm{g} / 1$ & $125 \mathrm{ml}$ & $500 \mathrm{ml}$ & $1500 \mathrm{ml}$ \\
BGAS (4) & $1.0 \mu \mathrm{g} / \mathrm{g}$ & $12.5 \mathrm{~g}$ & $50 \mathrm{~g}$ & $150 \mathrm{~g}$ \\
& $10 \mu \mathrm{g} / \mathrm{g}$ & $1.25 \mathrm{~g}$ & $5 \mathrm{~g}$ & $15 \mathrm{~g}$ \\
\hline
\end{tabular}

Therefore, the lowest dose with no hepatotoxic effects after i.p. injection was chosen $(25 \mu \mathrm{g} / \mathrm{kg}$ bw, (Kotak et al., 1993), multiplied by 10 for i.p. to p.o. extrapolation, divided by 10 for inter- and 10 for intra-species differences, ergo $2.5 \mu \mathrm{g} / \mathrm{kg}$ bw). The MC concentrations of the individual ingestion routes are based on literature information and discussed in the text. (1) Magalhaes et al., 2003; Mohamed et al., 2003; Vasconcelos, 1999; (2) Fastner et al., 1999; Fromme et al., 2000; Ueno et al., 1996; (3) Burns, 2004; Hitzfeld et al., 2000a,b; Hoeger et al., 2004a; Westrick, 2003; (4) Gilroy et al., 2000; Hoeger and Dietrich, 2004; Lawrence et al., 2001.

\section{Acute intoxication scenario}

The harmful concentrations for an acute intoxication with the most abundant cyanobacterial toxin in freshwater can be calculated as follows (Fromme et al., 2000): On the basis of mouse studies (Hooser et al., 1989; Kotak et al., 1993; Fawell et al., 1994; Yoshida et al., 1997), it can be assumed that a single intake of $12.5,50$ or $150 \mu \mathrm{g}$ MC-LR equiv. should not have adverse effects in toddlers $(5 \mathrm{~kg})$, young children $(20 \mathrm{~kg})$ and adults $(60 \mathrm{~kg})$, respectively. Both groups of children appear to be the age cohorts with the highest risks, because the MC levels are-as a result of the relatively low weight - within a range, which could be reached in different scenarios (summarised in Tables 3-5):

I. It is possible and in some regions worldwide the normal case that children consume more than $0.1 \mathrm{~kg}$ fish or shellfish per day (Mohamed et al., 2003). Calculated with the actual contaminations of fish and shellfish reported by Vasconcelos (1999), Magalhaes et al. (2001, 2003) and Mohamed et al. (2003) with MC-levels of up to $300 \mu \mathrm{g} / \mathrm{kg}$ edible fish, $2700 \mu \mathrm{g} / \mathrm{kg}$ crayfish and $16000 \mu \mathrm{g} / \mathrm{kg}$ mussels, it becomes obvious that in some regions worldwide, a risk for an acute poisoning of children through MCs in fish and shellfish exists (Table 5).

II. Children would most likely be playing and bathing in the shallow areas of surface waters where the waters are contaminated with MC- concentrations $>100 \mu \mathrm{g} / \mathrm{l}$ and consumption of 125 to $500 \mathrm{ml}$ of this highly contaminated water could already potentially result in an acute intoxication (Table 5). Infants playing in shallow water with a high density of perhaps decomposing cyanobacterial bloom could also potentially be highly endangered with respect to an intoxication with MCs, as bloom material may contain > $1000 \mu \mathrm{g}$ MCLR equiv./1 (Ueno et al., 1996).

III. It is unlikely, that concentrations of $25 \mu \mathrm{g}$ MC-LR equiv. or higher are incorporated via drinking water by children. However, concentrations of up to $100 \mu \mathrm{g}$ cylindrospermopsin, another highly potent cyanobacterial toxin, per litre final drinking water in Florida, USA (Burns, 2004), and the cases of death in Itaparica, Brasil ((Teixera et al., 1993), see above) show that there may be a further risk of an acute intoxication (Table 5).

IV. Infants and children are one of the target groups of BGAS, which contain up to $35 \mu \mathrm{g}$ MC-LR equiv./g dw (Lawrence et al., 2001). But even if the MC concentration is distinctly lower $(1-10 \mu \mathrm{g} / \mathrm{g})$, overzealous parents may potentially intoxicate their child, if they administer several grams of the BGAS daily (Table 5). Indeed, consumption of up to $20 \mathrm{~g}$ /day have been reported in case of an adult (Gilroy et al., 2000).

The above calculation is fraught with difficulties as it is presently unclear whether humans absorb MCs via the GI tract in amounts comparable to mice. However, it also should be considered that mice may be less prone to oral MC intoxications due to uptake limitations (see above), suggesting a potential for oral toxicity underestimation. Furthermore, mixtures of $\mathrm{MC}$ congeners may dictate different uptake situations. Thus the 12.5, 50 and $150 \mu \mathrm{g}$ MC-LR for toddlers, young children and adults as single doses can only serve as a rough approximation.

\section{Subchronic to chronic intoxication scenario}

I. The actual exposure of humans to MCs via food is rather difficult to estimate. Indeed, there is no general rule as to how much fish, shellfish, salad, rice, etc. is consumed daily per "international adult". Thus, the guidance values for MC contamination of foods must be calculated based on the local proclivities in food consumption and consequently must be carried out by the authorities of the individual country. For the purpose of this review, the guidance values for MCLR contamination of fish and shellfish were set according to the TDI calculated in Eqs. (1) and (2) (Table 3). From these calculations, it becomes obvious that children, as mentioned in the acute risk scenario, bear the highest risk of daily MC exposure. Additionally, some local populations largely dependant on one type of food source (e.g., fish, shellfish or crustaceans, rice) may be exposed either occasionally or chronically to high concentrations of MCs. However, in a worldwide view, the risk of uptake of MCs from contaminated foodstuffs appears low, at least for the general public.

II. High and therefore visible densities of cyanobacteria should prevent most people from swimming in such 
"contaminated" water bodies. However, according to correspondence with colleagues from all over the world, sometimes even major cyanobacterial blooms do not prevent water bodies from being used for recreational purposes. The possible ingestion of cyanobacterial toxins via this route is limited to the summer and fall season in more temperate climates. In contrast, in tropical regions a non-seasonal (all-year round) exposure of swimming and playing children is a distinct possibility. In several countries, warning signs have been installed at water bodies used for recreation to inform the public about the potential danger. However, these warning signs should not simply ban bathing (and the public do not know the reason), detailed information about the reason for the ban and the possible consequences of ignoring of the recommendation for humans and animals should be listed. This would enhance the success of these warning signs.

III. Contrary to the situation for food or water intake, where a natural limitation can be assumed, daily consumption of BGAS are largely dependent on the individual $(0.25-$ 20 g) (Gilroy et al., 2000; Schaeffer et al., 1999). In addition, water and food are usually consumed together, that is, in a meal, providing for a different gastrointestinal uptake scenario than for BGAS, which can be taken on an empty stomach. Thus, one can assume that self-medication or medication of children by their parents with BGAS is a scenario distinct from the typical variant exposure source scenario underlying the risk assessment calculation as foreseen in the IPCS (1995) documentation for the extrapolation of risk to humans from chemicals. Indeed, the BGAS uptake scenario is much more reminiscent of the administration of therapeutic compounds and should thus be treated entirely differently from the usual food and water-risk calculations. Similarly to the provisional WHO-guideline for drinking water, Gilroy et al. (2000) calculated a TDI of $0.04 \mu \mathrm{g}$ MC-LR/kg day based on the MC-LR mouse NOAEL of $40 \mu \mathrm{g} / \mathrm{kg}$ day defined by Fawell et al. (1999) and the application of a total of 1000-fold uncertainty factor (Table 4), which resulted in a provisional tolerable level for MCs in BGAS of 1.0 $\mu \mathrm{g}$ MC-LR/g dry weight. This level was adopted by the Oregon Health Division as a provisional regulatory standard for BGAS products on 23/10/1997. However, as this provisional tolerable level was calculated for an adult only, children (e.g., 10-20 kg body weight) would be exposed to three to six times the MC-LR equivalent concentration per day. Thus, in the worst case $(1.0 \mu \mathrm{g}$ MC-LR/g dw BGAS and daily intake of $10 \mathrm{~g}$ BGAS), children could ingest up to a 30 -fold amount of MC equivalents than that considered safe by the Oregon Health Division over weeks, months or even years. Moreover, as the levels of MCs in BGAS can exceed the provisional tolerable level for MCs in BGAS of $1.0 \mu \mathrm{g}$
MC-LR/g dry weight by up to a factor of 10 (Gilroy et al., 2000; Hoeger, 2003; Hoeger and Dietrich, 2004; Lawrence et al., 2001), the level of safety (original uncertainty factor of 1000 by Gilroy et al. (2000)) can shrink to 3 . However, if a more conservative TDI is employed the guidance value for MC-LR, even for adults of varying weight, falls below the $1 \mu \mathrm{g} / \mathrm{g} \mathrm{dw}$ level even if only $2 \mathrm{~g}$ of BGAS are consumed per day. The guidance values for MC-LR are not only driven by the amount of BGAS taken up daily but also by the body weight of the person consuming these products on a daily basis (Table 4). As BGAS are marketed with clear intention for supplementation of infants and children with ADHD (Lindermann, 1995), Table 4 clearly demonstrates that BGAS consumed at $2 \mathrm{~g}$ per day, even with a residual level of $1 \mu \mathrm{g}$ MC-LR/g dw, would exceed the TDI of infants and children by a factor 10-33 and 2.5-7.7, depending on the TDI chosen. If higher amounts are ingested daily, the TDI is exceeded by a multiple of the factors calculated for $2 \mathrm{~g}$ /day and in a worst case scenario ( $8 \mathrm{~g}$ BGAS per day) can exceed the TDI by a factor $40-123$ and 10-31 in infants and children. The fact that several independent analyses (Hoeger, 2003; Hoeger and Dietrich, 2004; Gilroy et al., 2000; Lawrence et al., 2001; Schaeffer et al., 1999) detected more than $1.0 \mu \mathrm{g}$ MC-LR equiv./g dw in 50$100 \%$ of the BGAS tested strongly suggests that higher exposures of consumers must be assumed than implicated by mere application of the Oregon Health Division provisional regulatory standard for these products on 23/10/1997. Indeed, these data and the comparison of guidance values calculated for BGAS applied to infants and children at various daily doses strongly demonstrate that the value of such a guidance is questionable. Clearly, if BGAS cannot be completely banned from the market, more conservative guidance values for MC content as well as a restriction for application to infants and children would be advisable if long-term health problems (chronic liver injury and potentially neuropathies and nephropathies) are to be avoided. Interestingly, a similar situation is presented in the case of seafood-derived complementary medicines in Australia, where dried shellfish meat products are self-prescribed by the patients. These shellfish capsules are suspected to contain a variety of biotoxins, for example, okadaic acid, a toxin with similar mode of action as the MCs (Llewellyn et al., 2004).

IV. Based on the knowledge that the amount of daily water consumption is naturally limited, guidance values for $\mathrm{MC}$ contamination in drinking water can be easily established (Tables 2,3). As already demonstrated for food intake, infants and children, although consuming less water per day, are potentially the most exposed. Thus, the guidance values for drinking water should clearly consider infants and children and not assume that differences in weight and consumption 
have already been factored into the uncertainty factors of the human intra-species variability (Fig. 1) as often purported. Indeed, the situation in Itaparica (Teixera et al., 1993), where a very high number of the cyanobacterial bloom and drinking water-associated mortalities were children, lends more support to the lowering of the guidance value for MCs in drinking water. Generally, the WHO guidance value for MC-LR in drinking water of $1.0 \mu \mathrm{g} / \mathrm{l}$ appears aiming to evaluate the risk of $\mathrm{MC}$ contamination in drinking water (Table 2), although small differences are associated with the different allocation of daily water intake and body weight. Although MCs can occur in high concentrations in raw waters, proper water treatment for drinking water purposes can reduce the MC content to a minimum (Hitzfeld et al., 2000a, 2000b; Hoeger, 2003; Hoeger et al., 2004a). Consequently, MC contamination of raw water is primarily a problem in those areas where no adequate water treatment is available. Thus, the WHO guideline value for drinking water of $1 \mu \mathrm{g}$ MC-LR/l, also reflecting the consensus amongst scientists, can be viewed as provisionally acceptable.

\section{Uncertainties in the detection methods}

Prerequisite for a guideline value is the availability of reliable detection methods. For the detection of MCs in drinking water, several methods exist and provide reliable results. Problems may arise if the matrix is complex and thus false positive and negative results can occur. The levels of MCs, which can be measured by ELISA, protein phosphatase assays as well as HPLC-DAD or MS largely depend on the preparation and detection methods used. For example, the detection of low amounts $(0.5-5.0 \mu \mathrm{g} / \mathrm{g})$ of $\mathrm{MC}$ in BGAS requires a much more complex preparation than the detection of low levels of MCs in drinking water. The detection of MCs in fish muscle or liver remains problematic. Indeed, due to the formation of covalent bonds between MCs and protein phosphatases, it is at present impossible to estimate how much of the detected MC in fish muscle or tissue is transferred within the food web, that is, is bioavailable for the next trophic level.

Overall, considering the enormous importance of proper detections of cyanotoxin contamination, the aspect of the appropriate preparation and detections systems must not be forgotten in future discussion of guideline values.

\section{Conclusions}

The data summarised in this review demonstrate that the present provisional guidance values can be exceeded dramatically, especially when using the more conservative TDI, and emphasises the importance of (i) establishment and validation of detection methods for MCs in complex matrices (ii) testing food for $\mathrm{MC}$ contamination and (iii) adjusting the guidance values for infants or children rather than using the "international adult" as a calculation basis. Although the standardised detection of MCs (nearly 80 congeners) is still a matter for future development and despite the detection-limitations discussed above, the current detection methods in water, foodstuffs and BGAS allow estimation of the actual MC-LR equivalent concentrations present. Consequently, a perfectioning of the sample preparation and detection methods and subsequently a more thorough monitoring of the food, water and BGAS contamination is advisable. A high degree of uncertainty remains as to the sufficiency of the uncertainty factors applied during extrapolation from animals to humans (factor 10), when considering the observed species (human-animal) differences in organic anion transporter profile (Fischer et al., 2004) and hence kinetic and dynamic dissimilarities (Batista et al., 2003). Although most acute and subchronic animal experiments have reported primarily liver pathology, some have also demonstrated nephropathy (Fischer and Dietrich, 2000a; Milutinovic et al., 2002; Miura et al., 1991; Nobre et al., 1999; Stotts et al., 1997), while the potential occurrence of neuropathy has largely been ignored, despite clinical indications in the Caruaru incident (Azevedo et al., 2002; Fischer et al., 2004; Pouria et al., 1998). The question remains to be resolved whether the endpoint for the pivotal study for human risk assessment should only include chronic liver injury (Falconer et al., 1994; Fawell et al., 1994, 1999) or the presence of preneoplastic lesions (Charbonneau et al., 2004), or whether indeed the development of an improved data base including nephropathy and neuropathy is more advisable. Furthermore, as the current risk assessment model is based primarily on MC-LR, an improved risk assessment using a MC-LR equivalents scheme, similar to the schemes already in place for dioxins and PCBs, thus including other congeners and incorporating the respective toxicokinetics and dynamic properties, would greatly reduce the degree of uncertainty and improve the risk assessment process.

Despite the above caveats, it appears that for the time being, the WHO guidance value for drinking water with $1.0 \mu \mathrm{g} \mathrm{MC}-\mathrm{LR} / 1$ should provide for sufficient protection of the consumer. In contrast, the application of guidance values for BGAS (Gilroy et al., 2000) appears misguided as the TDIs of infants and children, as well as adult consumers, are readily exceeded due to repeated contamination of BGAS and consumer dependent variation in daily BGAS consumption.

\section{Acknowledgments}

This review was funded by the EU project PEPCY (Toxic and bioactive peptides in cyanobacteria, QLRT-200102634). Special thanks to Dr. Evelyn O'Brien for very 
helpful comments and excellent correction of the manuscript. In addition, we wish to thank the reviewers for their constructive criticism.

\section{References}

Abe, T., Lawson, T., Weyers, J.D.B., Codd, G.A., 1996. Microcystin-LR inhibits photosynthesis of Phaseolus vulgaris primary leaves: Implications for current spray irrigation practice. New Phytol. 133, 651-658.

Annadotter, H., Cronberg, G., Lawton, L., Hansson, H.-B., Göthe, U., Skulberg, O.M., 2001. An extensive outbreak of gastroenteritis associated with the toxic cyanobacterium planktothrix agardhii (oscillatoriales, cyanophyceae) in scania, South Sweden. In: Chorus, I. (Ed.), Cyanotoxins. Springer, Berlin, pp. 200-208.

Azevedo, S.M., Carmichael, W.W., Jochimsen, E.M., Rinehart, K.L., Lau, S., Shaw, G.R., Eaglesham, G.K., 2002. Human intoxication by microcystins during renal dialysis treatment in Caruaru-Brazil. Toxicology 181-182, 441-446.

Batista, T., de Sousa, G., Strupi Suput, J., Rahmani, R., Suput, D., 2003. Microcystin-LR causes the collapse of actin filaments in primary human hepatocytes. Aquat. Toxicol. 65, 85-91.

Beasley, V.R., Coppock, R.W., Simon, J., Ely, R., Buck, W.B., Corley, R.A., Carlson, D.M., Gorham, P.R., 1983. Apparent blue-green algae poisoning in swine subsequent to ingestion of a bloom dominated by Anabaena spiroides. J. Am. Vet. Med. Assoc. 182, 413-414.

Beasley, V.R., Cook, W.O., Dahlem, A.M., Hooser, S.B., Lovell, R.A., Valentine, W.M., 1989a. Algae intoxication in livestock and waterfowl. Vet. Clin. North Am. 5, 345-361.

Beasley, V.R., Dahlem, A.M., Cook, W.O., Valentine, W.M., Lovell, R.A., Hooser, S.B., Harada, K.-I., Suzuki, M., Carmichael, W.W., 1989b. Diagnostic and clinically important aspects of cyanobacterial (bluegreen algae) toxicoses (Review). J. Vet. Diagn. Invest. 1, 359-365.

Beasley, V.R., Lovell, R.A., Holmes, K.R., Walcott, H.E., Schaeffer, D.J., Hoffmann, W.E., Carmichael, W.W., 2000. Microcystin-LR decreases hepatic and renal perfusion, and causes circulatory shock, severe hypoglycemia, and terminal hyperkalemia in intravascularly dosed swine. J. Toxicol. Environ. Health, Part A 61, 281-303.

Berg, K., Carmichael, W.W., Skulberg, O.M., Benestad, C., Underdal, B., 1987. Investigation of a toxic water-bloom of Microcystis aeruginosa (Cyanophyceae) in Lake Akersvatn, Norway. Hydrobiology 144, 97-103.

Bouaicha, N., Maatouk, I., 2004a. Genotoxic potential of microcystin-LR and nodularin in vitro in primary cultured rat hepatocytes and in vivo in rat liver cells. Sixth International Conference on Toxic Cyanobacteria, Bergen, Norway, pp. 13-14. Abstract.

Bouaicha, N., Maatouk, I., 2004b. Microcystin-LR and nodularin induce intracellular glutathione alteration, reactive oxygen species production and lipid peroxidation in primary cultured rat hepatocytes. Toxicol. Lett. $148,53-63$.

Burns, J., 2004. Cyanotoxins in Florida's surface waters: considerations for water supply planning. Sixth International Conference on Toxic Cyanobacteria Bergen, Norway, pp. 4. Abstract.

Carmichael, W.W., Beasley, V., Bunner, D.L., Eloff, J.N., Falconer, I., Gorham, P., Harada, K.-I., Yu, M.-J., Krishnamurthy, T., Moore, R.E., Rinehart, K., Runnegar, M.T.C., Skulberg, O.M., Watanabe, M., 1988. Naming of cyclic heptapeptide toxins of cyanobacteria (blue-green algae). Toxicon 26, 971-973.

Carmichael, W.W., Drapeau, C., Anderson, D.M., 2000. Harvesting of Aphanizomenon flos-aquae Ralfs ex Born. and Flah. var. flos-aquae (Cyanobacteria) from Klamath Lake for human dietary use. J. Appl. Phycol. 12, 585-595.

Charbonneau, M., Hitzfeld, B.C., Dietrich, D.R., 2004. Liver Preneoplasia in Rats Following an Initiation Promotion Protocol with Diethylnitrosamine and Microcystin-LR. Unpublished Results.

Codd, G.A., Metcalf, J.S., Beattie, K.A., 1999. Retention of Microcystis aeruginosa and microcystin by salad lettuce (Lactuca sativa) after spray irrigation with water containing cyanobacteria. Toxicon 37, $1181-1185$.

Craddock, A.L., Love, M.W., Daniel, R.W., Kirby, L.C., Walters, H.C., Wong, M.H., Dawson, P.A., 1998. Expression and transport properties of the human ileal and renal sodium-dependent bile acid transporter. Am. J. Physiol. 37, G157-G169.

Dahlem, A.M., Hassan, A.S., Waite, L.L., Carmichael, W.W., Beasley, V.R., 1989. Evidence for a role of glutathione in the toxicity of microcystinLR, a toxin from the cyanobacterium Microcystis aeruginosa. Toxicon 27, 39-40.

de Olivera Araújo, F., 1995. Effects of cyanobacteria on drinking water and human health: an epidemiological study in Évora, Portugal. In: Reichard, E.G., Zapponi, G.A. (Eds.), Assessing and Managing Health Risks from Drinking Water Contamination: Approaches and Applications. International Association of Hydrological Sciences (IAHS) Press, Wallingford, pp. 101-110.

Duy, T.N., Lam, P., Shaw, G., Connell, D., 2000. Toxicology and risk assessment of freshwater cyanobacterial (Blue-green algal) toxins in water. Rev. Environ. Contam. Toxicol. 163, 113-186.

Eriksson, J.E., Grönberg, L., Nygård, S., Slotte, J.P., Meriluoto, J.A.O., 1990a. Hepatocellular uptake of ${ }^{3} \mathrm{H}$-dihydromicrocystin-LR, a cyclic peptide toxin. Biochim. Biophys. Acta 1025, 60-66.

Eriksson, J.E., Toivola, D., Meriluoto, J.A., Karaki, H., Han, Y.G., Hartshorne, D., 1990b. Hepatocyte deformation induced by cyanobacterial toxins reflects inhibition of protein phosphatases. Biochem. Biophys. Res. Commun. 173, 1347-1353.

Eriksson, J.E., Brautigan, D.L., Vallee, R., Olmsted, J., Fujiki, H., Goldman, R.D., 1992. Cytoskeletal integrity in interphase cells requires protein phosphatase activity. Proc. Natl. Acad. Sci. U.S.A. 89, 11093-11097.

Ernst, B., Hitzfeld, B., Dietrich, D.R., 2000. Detection of cyanobacterial toxins in whitefish (Coregonus lavaretus) from Lake Ammersee. Toxicol. Sci. 54, 330. Abstract.

Ernst, B., Hitzfeld, B., Dietrich, D., 2001. Presence of Planktothrix sp. and cyanobacterial toxins in Lake Ammersee, Germany and their impact on whitefish (Coregonus lavaretus L.). Environ. Toxicol. 16, 483-488.

Falconer, I., 1991. Tumor promotion and liver injury cause by oral consumption of cyanobacteria. Environ. Toxicol. Water Qual. 6, 17-184.

Falconer, I.R., Jackson, A.R.B., Langley, J., Runnegar, M.T.C., 1981. Liver pathology in mice in poisoning by the blue-green alga Microcystis aeruginosa. Aust. J. Biol. Sci. 34, 179-187.

Falconer, I.R., Beresford, A.M., Runnegar, M.T.C., 1983. Evidence of liver damage by toxin from a bloom of the blue-green alga Microcystis aeruginosa. Med. J. Aust. 1, 511-514.

Falconer, I.R., Buckley, T., Runnegar, M.T., 1986. Biological half-life, organ distribution and excretion of 125I-labelled toxic peptide from the blue-green alga Microcystis aeruginosa. Aust. J. Biol. Sci. 39, 17-21.

Falconer, I.R., Smith, J.V., Jackson, A.R., Jones, A., Runnegar, M.T., 1988. Oral toxicity of a bloom of the cyanobacterium Microcystis aeruginosa administered to mice over periods up to 1 year. J. Toxicol. Environ. Health 24, 291-305.

Falconer, I., Burch, M., Steffensen, D., Choice, M., Coverdale, O., 1994. Toxicity of the blue-green alga (cyanobacterium) Microcystis aeruginosa in drinking water to growing pigs, as an animal model for human injury and risk assessment. J. Environ. Toxicol. Water Qual. 9, 131-139.

Fastner, J., Neumann, U., Wirsing, B., Weckesser, J., Wiedner, C., Nixdorf, B., Chorus, I., 1999. Microcystins (hepatotoxic heptapeptides) in German fresh water bodies. Environ. Toxicol. 14, 13-22.

Fawell, J., James, C., James, H., 1994. Toxins from blue-green algae: Toxicological assessment of Microcystin-LR and a method for its determination in water. Report No. FR 0359/2/D0E 3358/2, Foundation for Water Research, Marlow, UK, p. 46.

Fawell, J.K., Mitchell, R.E., Everett, D.J., Hill, R.E., 1999. The toxicity of cyanobacterial toxins in the mouse: I microcystin-LR. Hum. Exp. Toxicol. 18, 162-167.

Fessard, V., Le Hégarat, L., Mourot, A., 2004. Comparison of the genotoxic 
results obtained from the in vitro cytokinesis-block micronucleus assay with various toxins inhibitors of protein phosphatases: okadaic acid, nodularin and microcystin-LR. Sixth International Conference on Toxic Cyanobacteria, Bergen, Norway, p. 68. Abstract.

Fischer, W.J., Dietrich, D.R., 2000a. Pathological and biochemical characterization of microcystin-induced hepatopancreas and kidney damage in carp (Cyprinus carpio). Toxicol. Appl. Pharmacol. 164, 73-81.

Fischer, W.J., Dietrich, D.R., 2000b. Toxicity of the cyanobacterial cyclic heptapeptide toxins microcystin-LR and -RR in early life-stages of the African clawed frog (Xenopus laevis). Aquat. Toxicol. 49, 189-198.

Fischer, W.F., Hitzfeld, B.C., Tencalla, F., Eriksson, J.E., Mikhailov, A., Dietrich, D.R., 2000a. Microcystin-LR toxicodynamics, induced pathology and immunohistochemical localization in livers of bluegreen algae exposed rainbow trout (Oncorhynchus mykiss). Toxicol. Sci. 54, 365-373.

Fischer, W.J., Hitzfeld, B.C., Tencalla, F., Eriksson, J.E., Mikhailov, A., Dietrich, D.R., 2000b. Microcystin-LR toxicodynamics, induced pathology, and immunohistochemical localization in livers of bluegreen algae exposed rainbow trout (Oncorhynchus mykiss). Toxicol. Sci. 54, 365-373.

Fischer, W.J., Garthwaite, I., Miles, C.O., Ross, K.M., Aggen, J.B., Chamberlin, A.R., Towers, N.R., Dietrich, D.R., 2001. Congenerindependent immunoassay for microcystins and nodularins. Environ. Sci. Technol. 35, 4849-4856.

Fischer, W.J., Altheimer, S., Cattori, V., Meier, P.J., Dietrich, D.R., Hagenbuch, B., 2004. Organic anion transporting polypeptides (OATPs) mediate uptake of microcystin-LR into liver and brain. Toxicol. Appl. Pharmacol. special issue algal toxins, in press.

Fitzgeorge, R.B., Clark, S.A., Keevil, C.W., 1994. Routes of intoxication. In: Codd, G.A., Jefferies, T.M., Keevil, C.W., Potter, E. (Eds.), Detection methods for cyanobacterial toxins. Royal Society of Chemistry, Cambridge, UK.

Frimmer, M., Ziegler, K., 1988. The transport of bile acids in liver cells. Biochim. Biophys. Acta 947, 75-99.

Fromme, H., Koehler, A., Krause, R., Fuehrling, D., 2000. Occurrence of cyanobacterial toxins-microcystins and anatoxin-a-in Berlin water bodies with implications to human health and regulations. Environ. Toxicol. 15, 120-130.

Gilroy, D.J., Kauffman, K.W., Hall, R.A., Huang, X., Chu, F.S., 2000. Assessing potential health risks from microcystin toxins in bluegreen algae dietary supplements. Environ. Health Perspect. 108, $435-439$.

Habdous, M., Siest, G., Herbeth, B., Vincent-Viry, M., Visvikis, S., 2004. Glutathione S-transferases genetic polymorphisms and human diseases: overview of epidemiological studies. Ann. Biol. Clin. 62, 15-24.

Hagenbuch, B., Meier, P.J., 2003. The superfamily of organic anion transporting polypeptides. Biochim. Biophys. Acta 1609, 1-18.

Harada, K.-I., Tsuji, K., 1998. Persistence and decomposition of hepatotoxic microcystins produced by cyanobacteria in natural environment. J. Toxicol., Toxin Rev. 17, 385-403.

Harada, K., Ogawa, K., Matsuura, K., Murata, H., Suzuki, M., Watanabe, M.F., Itezono, Y., Nakayama, N., 1990a. Structural determination of geometrical isomers of microcystins LR and RR from cyanobacteria by two-dimensional NMR spectroscopic techniques. Chem. Res. Toxicol. $3,473-481$.

Harada, K.-I., Matsuura, K., Suzuki, M., Watanabe, M.F., Oishi, S., Dahlem, A.M., Beasley, V.R., Carmichael, W.W., 1990b. Isolation and characterization of the minor components associated with microcystins LR and RR in the cyanobacterium (blue-green algae). Toxicon 28, $55-64$.

Harada, K.-I., Tsuji, K., Watanabe, M.F., Kondo, F., 1996. Stability of microcystins from cyanobacteria: III. Effect of $\mathrm{pH}$ and temperature. Phycologia 35, 83-88.

Harada, K., Imanishi, S., Kato, H., Mizuno, M., Ito, E., Tsuji, K., 2004. Isolation of Adda from microcystin-LR by microbial degradation. Toxicon 44, 107-109.

Harding, W.R., Rowe, N., Wessels, J.C., Beattie, K.A., Codd, G.A., 1995.
Death of a dog attributed to the cyanobacterial (blue-green algal) hepatotoxin nodularin in South Africa. J. S. Afr. Vet. Assoc. 66, $256-259$

Henriksen, P., Moestrup, O., 1997. Seasonal variations in microcystin contents of Danish cyanobacteria. Nat. Toxins 5, 99-106.

Heresztyn, T., Nicholson, B.C., 2001. A colorimetric protein phosphatase inhibition assay for the determination of cyanobacterial peptide hepatotoxins based on the dephosphorylation of phosvitin by recombinant protein phosphatase 1. Environ. Toxicol. 16, 242-252.

Hermansky, S.J., Wolff, S.N., Stohs, S.J., 1990. Use of rifampin as an effective chemoprotectant and antidote against microcystin-LR toxicity. Pharmacology 41, 231-236.

Hermansky, S.J., Stohs, S.J., Eldeen, Z.M., Roche, V.F., Mereish, K.A., 1991. Evaluation of potential chemoprotectants against microcystin-LR hepatotoxicity in mice. J. Appl. Toxicol. 11, 65-73.

Hindman, S., Favero, M., Carson, L., Petersen, N., Schonberger, L., Solano, J., 1975. Pyrogenic reactions during hemodialysis caused by extramural endotoxin. Lancet 2, 732-734.

Hitzfeld, B., Lampert, C., Späth, N., Mountfort, D., Kaspar, H., Dietrich, D., 2000a. Toxin production in cyanobacterial mats from ponds on the McMurdo Ice Shelf, Antarctica. Toxicon 38, 1731-1748.

Hitzfeld, B.C., Hoeger, S.J., Dietrich, D.R., 2000b. Cyanobacterial toxins: removal during drinking water treatment, and human risk assessment. Environ. Health Perspect. 108 (Suppl. 1), 113-122.

Hoeger, S.J., 2003. Problems during drinking water treatment of cyanobacterial loaded surface waters: Consequences for human health, University of Konstanz, Germany (PhD Thesis).

Hoeger, S.J., Dietrich, D.R., 2004. Possible health risks arising from consumption of blue-green algae food supplements. Sixth International Conference on Toxic Cyanobacteria, Bergen, Norway, pp. 30. Abstract.

Hoeger, S.J., Hitzfeld, B.C., Dietrich, D.R., 2004a. Occurrence and elimination of cyanobacterial toxins in drinking water treatment plants. Toxicol. Appl. Pharmacol. (special issue algal toxins, in press).

Hoeger, S.J., Shaw, G., Hitzfeld, B.C., Dietrich, D.R., 2004b. Occurrence and elimination of cyanobacterial toxins in two Australian drinking water treatment plants. Toxicon 43, 639-649.

Hooser, S.B., 2000. Fulminant hepatocyte apoptosis in vivo following microcystin-LR administration to rats. Toxicol. Pathol. 28, $726-733$

Hooser, S.B., Beasley, V.R., Lovell, R.A., Carmichael, W.W., Haschek, W.M., 1989. Toxicity of microcystin-LR, a cyclic heptapeptide from Microcystis aeruginosa, to rats and mice. Vet. Pathol. 26, $246-252$.

Hooser, S.B., Kuhlenschmidt, M.S., Dahlem, A.M., Beasley, V.R., Carmichael, W.W., Haschek, W.M., 1991. Uptake and subcellular localization of tritiated dihydro-microcystin-LR in rat liver. Toxicon 29, $589-601$

IPCS, 1995. Assessing human health risks of chemicals: derivation of guidance values for health-based exposure limits. Environmental Health Criteria. WHO, Geneva, pp. 1-74.

Ito, E., Kondo, F., Terao, K., Harada, K.-I., 1997. Neoplastic nodular formation in mouse liver induced by repeated intraperitoneal injections of microcystin-LR. Toxicon 35, 1453-1457.

Jensen, G.S., Ginsberg, D.I., Drapeau, C., 2001. Blue-green algae as an immuno-enhancer and biomodulator. JANA 3, 24-30.

Kaebernick, M., Neilan, B.A., 2001. Ecological and molecular investigations of cyanotoxin production. FEMS Microbiol. Ecol. 35, 1-9.

Kankaanpää, H.T., Sipiä, V.O., Karlsson, K., Huttunen, M., Turunen, A.K., Meriluoto, J.A.O., 2004. Pathways of cyanobacterial liver toxins in the Baltic sea. Sixth International Conference on Toxic Cyanobacteria, Bergen, pp. 24. Abstract.

Kondo, F., Ikai, Y., Oka, H., Okumura, M., Ishikawa, N., Harada, K.-I., Matsuura, K., Murata, H., Suzuki, M., 1992. Formation, characterization, and toxicity of the glutathione and cysteine conjugates of toxic heptapeptide microcystins. Chem. Res. Toxicol. 5, 591-596.

Kotak, B.G., Kenefick, S.L., Fritz, D.L., Rousseaux, C.G., Prepas, E.E., Hrudey, S.E., 1993. Occurrence and toxicological evaluation of 
cyanobacterial toxins in Alberta lakes and farm dugouts. Water Res. 27, $495-506$

Krienitz, L., Ballot, A., Kotut, K., Wiegand, C., Puetz, S., Metcalf, J.S., Codd, G.A., Pflugmacher, S., 2003. Contribution of hot spring cyanobacteria to the mysterious deaths of Lesser Flamingos at Lake Bogoria, Kenya. FEMS Microbiol. Ecol. 43, 141-148.

Kuiper-Goodman, T., Gupta, S., Combley, H., Thomas, B.H., 1994. Microcystins in drinking water: risk assessment and derivation of a possible guidance value for drinking water. In: Steffensen, D.A., Nicholson, B.C. (Eds.), Toxic Cyanobacteria: Current Status of Research and Management. Australian Centre for Water Quality Research, Salisbury, pp. 67-73.

Kuiper-Goodman, T., Falconer, I.R., Fitzgerald, D.J., 1999. Human health aspects. In: Chorus, I., Bartram, J. (Eds.), Toxic Cyanobacteria in Water: a Guide to their Public Health Consequences, Monitoring and Management. E and FN Spon, London, pp. 114-153.

Kullak-Ublick, G.A., Beuers, U., Paumgartner, G., 1996. Molecular and functional characterization of bile acid transport in human hepatoblastoma HepG2 cells. Hepatology 23, 1053-1060.

Kullak-Ublick, G.-A., Fisch, T., Oswald, M., Hagenbuch, B., Meier, P.J., Beuers, U., Paumgärtner, G., 1998. Dehydroepiandrosterone sulfate (DHEAS): identification of a carrier protein in human liver and brain. FEBS Lett. 424, 173-176.

Kusuhara, H., Sekine, T., Utsunomiya-Tate, N., Tsuda, M., Kojima, R., Cha, S.H., Sugiyama, Y., Kanai, Y., Endou, H., 1999. Molecular cloning and characterization of a new multispecific organic anion transporter from rat brain. J. Biol. Chem. 274, 13675-13680.

Landi, S., 2000. Mammalian class Theta GST and differential susceptibility to carcinogens: a review. Mutat. Res. 463, 247-283.

Lankoff, A., Krzowski, L., Glab, J., Banasik, A., Lisowska, H., Kuszewski, T., Gozdz, S., Wojcik, A., 2004. DNA damage and repair in human peripheral blood lymphocytes following treatment with microcystinLR. Mutat. Res. 559, 131-142.

Lawrence, J.F., Niedzwiadek, B., Menard, C., Lau, B.P., Lewis, D., KuiperGoodman, T., Carbone, S., Holmes, C., 2001. Comparison of liquid chromatography/mass spectrometry, ELISA, and phosphatase assay for the determination of microcystins in blue-green algae products. J. AOAC Int. 84, 1035-1044.

Lindermann, B., 1995. Complicated Child? Simple Options. Ransom Hill Press, Ramona, CA, USA.

Llewellyn, L.E., Robillot, C.E., Negri, A.P., 2004. Inappropriate use of food quality standards for seafood-derived complementary medicines. Med. J. Aust. 180, 250-251.

MacKintosh, C., Beattie, K.A., Klumpp, S., Cohen, P., Codd, G.A., 1990. Cyanobacterial microcystin-LR is a potent and specific inhibitor of protein phosphatases 1 and 2A from both mammals and higher plants. FEBS Lett. 264, 187-192.

Magalhaes, V.F., Soares, R.M., Azevedo, S.M., 2001. Microcystin contamination in fish from the Jacarepagua Lagoon (Rio de Janeiro, Brazil): ecological implication and human health risk. Toxicon 39, 1077-1085.

Magalhaes, V.F., Marinho, M.M., Domingos, P., Oliveira, A.C., Costa, S.M., Azevedo, L.O., Azevedo, S.M., 2003. Microcystins (cyanobacteria hepatotoxins) bioaccumulation in fish and crustaceans from Sepetiba Bay (Brasil RJ). Toxicon 42, 289-295.

Meier, P.J., 1996. Hepatocellular transport systems: from carrier identification in membrane vesicles to cloned proteins. J. Hepatol. 24, 29-35.

Meier, P.J., Stieger, B., 2002. Bile salt transporters. Annu. Rev. Physiol. 64, $635-661$

Meier, P.J., Eckhardt, U., Schroeder, A., Hagenbuch, B., Stieger, B., 1997. Substrate specificity of sinusoidal bile acid and organic anion uptake systems in rat and human liver. Hepatology 26, 1667-1677.

Meriluoto, J.A.O., Nygård, S., Dahlem, A.M., Eriksson, J.E., 1990. Synthesis, organotropism and hepatocellular uptake of two tritiumlabeled epimers of dihydromicrocystin-LR, a cyanobacterial peptide toxin analog. Toxicon 28, 1439-1446.
Mez, K., Beattie, K., Codd, G., Hanselmann, K., Hauser, B., Naegeli, H., Preisig, H., 1997. Identification of a microcystin in benthic cyanobacteria linked to cattle deaths on alpine pastures in Switzerland. Eur. J. Phycol. 32, 111- 117 .

Milutinovic, A., Sedmak, B., Horvat-Znidarsic, I., Suput, D., 2002. Renal injuries induced by chronic intoxication with microcystins. Cell. Mol. Biol. Lett. 7, 139-141.

Miura, G.A., Robinson, N.A., Lawrence, W.B., Pace, J.G., 1991. Hepatotoxicity of microcystin-LR in fed and fasted rats. Toxicon 29, $337-346$.

Mohamed, Z.A., Carmichael, W.W., Hussein, A.A., 2003. Estimation of microcystins in the freshwater fish Oreochromis niloticus in an Egyptian fish farm containing a Microcystis bloom. Environ. Toxicol. $18,137-141$.

Mundt, S., Kreitlow, S., Nowotny, A., Effmert, U., 2001. Biochemical and pharmacological investigations of selected cyanobacteria. Int. J. Hyg. Environ. Health 203, 327-334.

Nishiwaki, R., Ohta, T., Sueoka, E., Suganuma, M., Harada, K.-I., Watanabe, M.F., Fujiki, H., 1994. Two significant aspects of microcystin-LR: specific binding and liver specificity. Cancer Lett. 83, 283-289.

Nishiwaki-Matsushima, R., Ohta, T., Nishiwaki, S., Suganuma, M., Kohyama, K., Ishikawa, T., Carmichael, W.W., Fujiki, H., 1992. Liver tumor promotion by the cyanobacterial cyclic peptide toxin microcystin-LR. J. Cancer Res. Clin. Oncol. 118, 420-424.

Nobre, A.C.L., Jorge, M.C.M., Menezes, D.B., Fonteles, M.C., Monteiro, H.S.A., 1999. Effects of microcystin-LR in isolated perfused rat kidney. Br. J. Med. Biol. Res. 32, 985-988.

Nobre, A.C., Coelho, G.R., Coutinho, M.C., Silva, M.M., Angelim, E.V., Menezes, D.B., Fonteles, M.C., Monteiro, H.S., 2001. The role of phospholipase A2 and cyclooxygenase in renal toxicity induced by microcystin-LR. Toxicon 39, 721-724.

Orr, P.T., Jones, G., Hunter, R.A., Berger, K., De Paoli, D.A., Orr, C.L.A., 2001. Ingestion of toxic Microcystis aeruginosa by dairy cattle and the implications for microcystin contamination of milk. Toxicon 39, $1847-1854$.

Orr, P.T., Jones, G.J., Hunter, R.A., Berger, K., 2003. Exposure of beef cattle to sub-clinical doses of Microcystis aeruginosa: toxin bioaccumulation, physiological effects and human health risk assessment. Toxicon 41, 613-620.

Pace, J.G., Robinson, N.A., Miura, G.A., Lynch, T.G., Templeton, C.B., 1990. Pharmacokinetics, metabolism and distribution of microcystin ([3H]Mcyst-LR) in the rat. Toxicologist 10, 219.

Park, H.-D., Watanabe, M.F., Harada, K.-I., Nagai, H., Suzuki, M., Watanabe, M., Hayashi, H., 1993. Hepatotoxin (microcystin) and neurotoxin (anatoxin-a) contained in natural blooms and strains of cyanobacteria from Japanese freshwaters. Nat. Toxins 1, 353-360.

Pennycott, T., Young, F.M., Metcalf, J.S., Codd, G.A., 2004. Necrotic enteritis in mute swans associated with cyanobacterial toxins. Vet. Rec. 154, 575-576.

Pereira, P., Onodera, H., Andrinolo, D., Franca, S., Araujo, F., Lagos, N., Oshima, Y., 2000. Paralytic shellfish toxins in the freshwater cyanobacterium Aphanizomenon flos-aquae, isolated from Montargil reservoir, Portugal. Toxicon 38, 1689-1702.

Pouria, S., de Andrade, A., Barbosa, J., Cavalcanti, R., Barreto, V., Ward, C., Preiser, W., Poon, G., Neild, G., Codd, G., 1998. Fatal microcystin intoxication in haemodialysis unit in Caruaru, Brazil. Lancet 352, 21-26.

Puschner, B., Galey, F.D., Johnson, B., Dickie, C.W., Vondy, M., Francis, T., Holstege, D.M., 1998. Blue-green algae toxicosis in cattle. Journal of the American Veterinary Medical Association 213, 1571, 1605-1607.

Rahman, M., Podder, A.K., van Hove, C., Begum, T., Heulin, T., Hartmann, A., 1996. Biological Nitrogen Fixation Associated with Rice Production. Kluwer Academic Publisher, Dordrecht.

Robinson, N.A., Miura, G.A., Matson, C.F., Dinterman, R.E., Pace, J.G., 1989. Characterization of chemically tritiated microcystin-LR and its distribution in mice. Toxicon 27, 1035-1042.

Robinson, N.A., Pace, J.G., Matson, C.F., Miura, G.A., Lawrence, W.B., 
1991. Tissue distribution, excretion and hepatic biotransformation of microcystin-LR in mice. J. Pharmacol. Exp. Ther. 256, 176-182.

Runnegar, M.T.C., Gerdes, R.G., Falconer, I.R., 1991. The uptake of the cyanobacterial hepatotoxin microcystin by isolated rat hepatocytes. Toxicon 29, 43-51.

Runnegar, M., Berndt, N., Kaplowitz, N., 1995. Microcystin uptake and inhibition of protein phosphatases: effects of chemoprotectants and selfinhibition in relation to known hepatic transporters. Toxicol. Appl. Pharmacol. 134, 264-272.

Sano, T., Takagi, H., Sadakane, K., Ichinose, T., Kawazato, H., Kaya, K., 2004. Carcinogenic effects of microcystin-LR and Dhb-microcystin-LR on mice liver. Sixth International Conference on Toxic Cyanobacteria, Bergen, Norway, pp. 59. Abstract.

Schaeffer, D., Malpas, P., Barton, L., 1999. Risk assessment of microcystin in dietary Aphanizomenon flos-aquae. Ecotoxicol. Environ. Saf. 44, $73-80$.

Schmid, D., Ernst, B., Hoeger, S.J., Dietrich, D.R., 2004. Characterization and differentiation of two microcystins from Planktothrix spec. isolated from a pre-alpine lake in Europe. Sixth International Conference on Toxic Cyanobacteria, Bergen, Norway, pp. 79. Abstract.

Sivonen, K., Jones, G., 1999. Cyanobacterial toxins. In: Chorus, I. Bartram, J. (Eds.), Toxic Cyanobacteria in Water: a Guide to their Public Health Consequences, Monitoring and Management. E and FN Spon, London, pp. 41-111.

Stotts, R.R., Twardock, A.R., Haschek, W.M., Choi, B.W., Rinehart, K.L., Beasley, V.R., 1997. Distribution of tritiated dihydromicrocystin in swine. Toxicon 35, 937-953.

Takenaka, S., 2001. Covalent glutathione conjugation to cyanobacterial hepatotoxin microcystin LR by F344 rat cytosolic and microsoma glutathione S-transferase. Environ. Toxicol. Pharmacol. 9, 135-139.

Takikawa, H., 2002. Hepatobiliary transport of bile acids and organic anions. J. Hepato-biliary Pancr. Surg. 9, 443-447.

Teixera, M., Costa, M., Carvalho, V., Pereira, M., Hage, E., 1993. Gastroenteritis epidemic in the area of the Itaparica Dam, Bahia, Brazil. Bull. Pan Am. Health Org. 27, 244-253.

Ueno, Y., Nagata, S., Tsutsumi, T., Hasegawa, A., Yoshida, F., Suttajit, M., Mebs, D., Pütsch, M., Vasconcelos, V., 1996. Survey of microcystins in environmental water by a highly sensitive immunoassay based on monoclonal antibody. Nat. Toxins 4, 271-276.

Vasconcelos, V.M., 1999. Cyanobacterial toxins in Portugal: effects on aquatic animals and risk for human health. Br. J. Med. Biol. Res. 32, $249-254$

Westrick, J.A., 2003. Everything a manager should know about algal toxins but was afraid to ask. AWWA, 26-34

WHO, 1998. Cyanobacterial toxins: Microcystin-LR. Guidelines for Drinking-Water Quality. World Health Organization, Geneva, pp. $95-110$

Wickstrom, M.L., Khan, S.A., Haschek, W.M., Wyman, J.F., Eriksson, J.E., Schaeffer, D.J., Beasley, V.R., 1995. Alterations in microtubules, intermediate filaments, and microfilaments induced by microcystinLR in cultured cells. Toxicol. Pathol. 23, 326-337.

Wiedner, C., Chorus, I., Fastner, J., 2001. The waterbodies surveyed for cyanotoxins in Germany. In: Chorus, I. (Ed.), Cyanotoxins. Springer, Berlin, pp. 6-45.

Willett, K.L., Roth, R.A., Walker, L., 2004. Workshop overview: hepatotoxicity assessment for botanical dietary supplements. Toxicol. Sci. 79, 4-9

Wynn-Williams, D.D., 2000. Cyanobacteria in the Deserts-Life at the Limit? In: Whitton, B.A., Potts, M. (Eds.), The Ecology of Cyanobacteria. Kluwer Academic Publishers, Dordrecht, pp. 341-366.

Xu, L.H., Lam, P.K.S., Chen, J.P., Xu, J.M., Wong, B.S.F., Zhang, Y.Y., Wu, R.S.S., Harada, K.I., 2000. Use of protein phosphatase inhibition assay to detect microcystins in Donghu Lake and a fish pond in China. Chemosphere 41, 53-58.

Yoshida, T., Makita, Y., Tsutsumi, T., Yoshida, F., Sekijima, M., Tamura, S.-I., Ueno, Y., 1997. Acute oral toxicity of microcystin-LR, a cyanobacterial hepatotoxin, in mice. Nat. Toxins 5, 91-95.

Yu, S.-Z., 1995. Prevention of hepatocellular carcinoma. J. Gastroenterol. Hepatol. 10, 674-682.

Zegura, B., Sedmak, B., Filipic, M., 2003. Microcystin-LR induces oxidative DNA damage in human hepatoma cell line HepG2. Toxicon $41,41-48$.

Zilberg, B., 1966. Gastroenteritis in Salisbury European children-a fiveyear study. Cent. Afr. J. Med. 12, 164-168. 